\title{
Wisdom Has Built Her House (Proverbs 9, 1-6). The History of THE Notion IN SOUTHERN AND Eastern Slavic Art in the $14^{\mathrm{TH}}-16^{\mathrm{TH}}$ Centuries ${ }^{*}$
}

\author{
Wisdom has built her house; \\ she has set up a its seven pillars. \\ She has prepared her meat and mixed her wine; \\ she has also set her table. \\ She has sent out her servants, and she calls \\ from the highest point of the city, \\ "Let all who are simple come to my house!" \\ To those who have no sense she says, \\ "Come, eat my food \\ and drink the wine I have mixed. \\ Leave your simple ways and you will live; \\ walk in the way of insight"
}

\section{$\mathrm{T}$} he story of the personified Divine Wisdom, building a house for herself, and then organizing a feast in it, mentioned in the ninth chapter of the Old Testament Book of Proverbs, seems to be - through its pictorial quality - a perfect theme for artists concerned with plastic creativity. What astonishes us is the fact that this motif was virtually absent in Eastern Christian Art until the turn of the $14^{\text {th }}$ century. As emphasized jointly by experts on this issue, to this day no artefact of Byzantine provenance containing a representation of Sophia inviting people who want to accompany her to a feast has been preserved ${ }^{1}$. In the older literature

\footnotetext{
* This article has been written under the research project financed by the National Science Centre (Poland). Decision number: DEC-2011/03/N/HS2/00890 (Sophia - the Personification of Divine Wisdom: the History of the Notion in the Byzantine-Slavonic Culture).

${ }^{1}$ Т.А. СидоровА, Волотовская фреска "Премудрость созда себе дом" и ее отночение к новгородской ереси стригольников в ХІV в., ТОДЛ 26, 1971, p. 222; D.F. FIENE, What is the Appearance of Divine Sophia?, SRev 48, 1989, p. 454; Л.М. ЕвсеввА, Пир Премудрости, [in:] София Премудрость Божия. Выставка русской иконописи XIII-XIX вв. из собраний музеев России, Москва 2000, p. 194 (Italian version of the article in: Sophia. La Sapienza di Dio, ed. G.C. Azzaro, P. Azzaro, Milano 1999, p. 226-229); Н.В. Покровский, Евангелие в памятниках иконографии преимущественно византийских и русских, Москва 2001, р. 465; В.Г. БрюсовА, Собия Премудрость Божия в древнерусской титературе и искусстве, Москва 2006, p. 65-66. Galina S. Kolpakova claims that this type of work, prepared around 1263, was included in the painting which decorates the interior of the Hagia Sophia temple in Trebizond. Г.С. КолпАковА, Искусство Византии. Позд-
} 
on the subject one might come across the idea that the issue was initially found in the manuscript painting of the Latin circle, which then, at the end of the Middle Ages, moved to the Balkans ${ }^{2}$. While we do not have enough source material to incline us towards a thesis supporting the Western European origins of the iconographic scheme discussed in this article, so we can not deny that it is in the area of Serbia and western Bulgaria that the earliest examples of iconography relating to the Book of Proverbs 9, 1-6 are known. Moreover, there is no doubt that their dissemination across the lands of the Southern Slavs is inscribed into a broader cultural movement characterized by the return to ancient aesthetics, referred to in the literature as the Paleologian Renaissance ${ }^{3}$.

Certainly the oldest example of the iconography of Sophia's banquet, which has survived to the present day, is a painting located on the southern wall of the narthex of the Mother of God Peribleptos and St. Clement Church in Ohrid, dated back to $1295^{4}$. The personified Wisdom was located here on the left side of the

ний период, Санкт-Петербург 2010, p. 69-70, 78, 287. Sirarpie der Nersessian assumes that the representation referring to Prov 9, 1-6 adorned a part of the dome of the church of the Holy Apostles in Thessalonica. The representation preserved in fragments shows some stylistic similarity to the representations of Sophia's banquet, which we know from South Slavic art. However, it does not include the most important element from the point of view of our considerations: the personification of Divine Wisdom. In the center of the work on the analyzed painting there is a male figure, which is sometimes interpreted in the literature as a portrait of King Solomon. S. DER Nersessian, Program and Iconography of the Frescoes of the Parecclesion, [in:] The Kariye Djami, vol. IV, Studies in the Art of the Kariye Djami and Its Intellectual Background, ed. P.A. Underwood, London 1975, p. 341-342. ${ }^{2}$ K.C. Felmy, "Die unendliche Weisheit, des Lebens Allgrund und Erschafferin". Die Ikonen der Weisheit und die Göttliche Liturgie, [in:] "Die Weisheit baute ihr Haus". Untersuchungen zu Hymnischen und Didaktischen Ikonen, ed. K.C. Felmy, E. Haustein-Bartsch, München 1999, p. 49; Н.В. Покровский, op. cit., p. 465; В.Г. БрюсовА, op. cit., p. 66.

${ }^{3}$ J. Meyendorff, L'iconographie de la Sagesse Divine dans la tradition byzantine, CAr 10, 1959, p. 270; A. Grabar, Sur les sources des peintres byzantins des XIII et XIV siècles, CAr 12, 1962, p. 379; S. DER Nersessian, Note sur quelques image se rattachant au thème du Christ-Ange, CAr 13, 1962, p. 209; Т.А. Сидорова, op. cit., p. 214, 222; J. MeyendorfF, Wisdom-Sophia: Contrasting Approaches to a Complex Theme, DOP 41, 1987, p. 391, 393; L. Uspienski, Teologia ikony, trans. B. DĄB-Kalinowska, Poznań 1993, p. 195; Л.M. ЕвсеввA, op. cit., p. 194. The problem of influence of the Palaeologian Renaissance and hesychasm on the development of iconography of Divine Wisdom in $14^{\text {th }}$ century has been analysed the monograph: Z. Brzozowska, Sofia - upersonifikowana Mądrość Boża. Dzieje wyobrażeń w kręgu kultury bizantyńsko-słowiańskiej, Łódź 2015, p. 49-55, 198-226.

${ }^{4}$ V.R. Petković, La peinture Serbe du Moyen Âge, vol. I, Belgrad 1930, p. V, 24; I.D. ŞTEFĂNEscu, L'illustration des liturgies dans l'art de Byzance et de l'Orient, Bruxelles 1936, p. 140; A.M. AmmanN, Darstellung und Deutung der Sophia im vorpetrinischen Russland, OCP 4, 1938, p. 144; J. MeYENDorff, L'iconographie..., p. 270; С. РАдојчић, Фреске Марковог Манастира и живот св. Васитија Новог, ЗРВИ 4, 1956, p. 223; S. Der Nersessian, Note..., p. 209; Т.А. Сидорова, op. cit., p. 222; Л. Прашков, Хрелева башня Рильского монастыря и ее стенопись, [in:] Древнерусское искусство. Зарубежные связи, Москва 1975, p. 155; S. Radојс̌ı́́, La table de la Sagesse dans la literature et l'art serbes, ЗРВИ 16, 1975, p. 221; Л.М. ЕвСЕевА, Две символические композиции в росписи ХІV в. Монастыря Зарзма, ВВ 43, 1982, р. 139; С. РАдолчић, О Трпези Премудрости у српској кюижевности и уметности од раног ХIII до раног XIX в., [in:] IDEM, Одабрани чланци и студије 
iconographic scheme, giving her the form of a young woman clad in ancient Greek attire (blue-purple chiton with short sleeves, with a gold ribbon around the neck). Sophia sits on a throne, holding her bare feet on a footrest. With her left hand she points to the table in front of her. Her head is uncovered and long, dark brown hair is supported with a band. Behind the Divine Wisdom there is a pair of outstretched wings 5 .

Also noteworthy is the inclusion in the analyzed artefact of many elements from the so-called "Wisdom iconography of light", which is, according to Priscilla Hunt, a reference to the representation of Wisdom as one of the energies of God, typical of the theological thought of Gregory Palamas. The head of Sophia is

1933-1978, Београд-Нови Сад 1982, р. 227; Г.М. Прохоров, Послание Титу-иерарху Дионисия Ареопагита в славянском переводе и иконограбия "Премудрость созда себе дом", ТОДЛ 38, 1985, р. 8; И.Ф. МейендорФ, Тема Премудрости в восточноевропейской средневековой культуре и ее наследие, [in:] Литература и искусство в системе культуры, еd. Б.Б. Пиотровский, Москва 1988, p. 246; IDEM, Wisdom-Sophia..., p. 394; P. BALCAREK, The Image of Sophia in Medieval Russian Iconography and its Sources, Bsl 60, 1999, p. 600; K.C. Felmy, op. cit., p. 43; L. LifšIC, Die Ikone "Sophia - Weisheit Gottes" aus der Sammlung der Museen des Moskauer Kreml'. Zur Frage nach der Herkunft und der Zeit des ersten Auftauchens des sogenannten "Novgoroder" ikonographischen Typs, [in:] "Die Weisheit baute ihr Haus"..., p. 31; M.V. Marini Clarelli, Personificazioni, metafore e alegorie nell'arte paleologa, [in:] L'arte di Bisanzio e l'Italia al tempo del Paleologi 1261-1453, ed. A. Iacobini, M. Della Valle, Roma 1999, p. 58; L. Lifšic, La Sapienza nell'iconografia russa, [in:] Sophia. La Sapienza di Dio..., p. 59; Л.М. Евсеева, Пир Премудрости..., p. 194; Л. Лифшиц, София Премудрость Божия в русской иконописи, [in:] София Премудрость Божия..., p. 11; Н. Пивоварова, Премудрость и Церковь, [in:] Собия Премудрость Божия..., p. 324 (Italian version of the article in: Sophia. La Sapienza di Dio..., p. 358-359); Л. Лифшиц, Премудрость в русской иконописи, ВВ 61, 2002, р. 140, 142; М.Н. Громов, Образ сакральной Премудрости, [in:] М.Н. Громов, В.В. Мильков, Идейные течения древнерусской мысли, Санкт-Петербург 2001, p. 56; M. Osterrieder, Das Land der Heiligen Sophia: das Auftauchen des Sophia-motivs in der Kultur der Ostslaven, WSA 50, 2002, p. 41; В.Г. БрюсовА, ор. cit., p. 67; И.М. ЂорЂЕвић, Дарови Светог Духа у проскомидији Богородичине иркве у Морачи, [in:] The Monastery of Morača, ed. B. Todić, D. Popović, Belgrade 2006, p. 196; A. Deyneka, The Ackland Sophia: Contextualizing, Interpreting, and "Containing" Wisdom, Chapel Hill 2007, p. 34; V. TsAmAKDA, Darstellungen der Hagia Sophia bzw. der Weisheit Gottes in der kretischen Wandmalerei, BZ 101, 2008, p. 227; С. ЗОлОтАРев, София Премудрость Божия. Проблемы и перспективы религиозно-философского и искусствоведческого осмысления, ГРЦР 44/45, 2008, р. 299-300; Е.Б. ГромовА, “Премудрость созда себе дом" в богословской и изобразительной традиции XIV в., [in:] Сербско-русские титературные и культурные связи XIV-XX вв., еd. Л.К. ГАврюшинА, Санкт-Петербург 2009, р. 7; Г.С. КОЛПАКОвА, ор. cit., p. 77-78, 287; М. ЧХенКЕли, Символическая связь Премудрости Божией и Евхаристии в сербском монументальном искусстве XIII-XIV в., CRe 4, 2010, p. 134.

${ }^{5}$ J. Meyendorf, L'iconographie..., p. 270; Т.А. СидоровА, op. cit., p. 222; Г.М. Прохоров, op. cit., p. 9; К.С. Felmy, op. cit., p. 43; L. LifšıC, La Sapienza..., p. 59; Л.М. ЕвсеевА, Пир Премудрости..., p. 194; Л. Лифшиц, София Премудрость Божия..., p. 11; IDEм, Премудрость..., p. 142; M. Osterrieder, op. cit., p. 41; И.М. ЂОРЂЕвИћ, op. cit., p. 196; С. ЗОлОтАРев, op. cit., p. 300; М. ЧХенКЕлИ, op. cit., p. 134.

${ }^{6} \mathrm{P}$. Hunt, The Wisdom Iconography of Light. The Genesis, Meaning and Iconographic Realization of a Symbol, Bsl 67, 2009, p. 103. 
adorned with a glory composed of two figures: a blue rhombus and a gold circle in which a cross is inscribed (typical for the images of Christ) ${ }^{7}$. Moreover, the figure of personified Wisdom is surrounded by several concentric circles and her silhouette seems to shed rays of light ${ }^{8}$.

The Ohrid depiction is a fairly faithful illustration of the text of Prov 9, 1-6. Next to the figure of Sophia there is a table on which is a bowl for bread, a jug of wine and

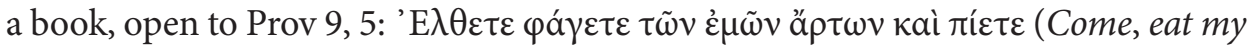
bread, and drink the wine which I have mingled for you!) ${ }^{9}$. The items placed on the table as well as the above-cited quotation seem to be a clear allusion to the sacrament of Eucharist ${ }^{10}$. On the right side of the iconographic scheme three servants of Sophia are represented, giving them the shapes of enticing young women, dressed - like their lady - in the ancient style. One of them is holding an amphora in her hand, whereas the other two carry loaves of bread ${ }^{11}$. Behind them there is a large building in the shape of a three-aisled basilica, surrounded by a portico, where you can easily see seven columns. Most likely, there is a depiction of Wisdom's House, described in the Book of Proverbs, which is supported by seven pillars ${ }^{12}$.

\footnotetext{
7 I.D. ŞTefănescu, op. cit., p. 140; J. Meyendorff, L'iconographie..., p. 270; S. DER Nersessian, Note..., p. 215; EAdem, Program..., p. 341; P. BalCareK, op. cit., p. 600; M.V. Marini Clarelli, op. cit., p. 58; Л.М. ЕвсеевА, Пир Премудрости..., p. 194; М. Osterrieder, op. cit., p. 41; И.М. ЂОРЂЕВИЋ, op. cit., p. 196; С. ЗОЛОтАРев, оp. cit., p. 300; М. ЧХенкЕЛИ, op. cit., p. 134. In Eastern Christian literature, starting from the times of the Fathers of the Church, the Old Testament Wisdom was usually identified with the second person of the Trinity - the Son of God. The Hagia Sophia churches in Byzantium were devoted to him, the theological treatises and hymnographic texts (for example the canon for Holy Thursday by Cosmas of Maiuma) were written in honour of him and he was represented on "Sophia" icons. I have attempted to analyse this issue in: Z. BrzozowsKA, The Church of Divine Wisdom or of Christ - the Incarnate Logos? Dedication of Hagia Sophia in Constantinople in the Light of Byzantine Sources from $5^{\text {th }}$ to $14^{\text {th }}$ century, SCer 2, 2012, p. 85-96; EADEM, Sofia - Mądrość Boża. Przymiot, energia czy odrębna osoba Boska w teologii Kościoła wschodniego (do XV w.), Hy 20, 2013, p. 1-21; EAdem, Sofia - upersonifikowana Mądrość Boża..., p. 22-86.

${ }^{8}$ T.А. СидоровА, op. cit., p. 222; К.С. FеLму, op. cit., p. 43.

9 J. Meyendorff, L'iconographie..., p. 270; S. Der Nersessian, Note..., p. 215; Eadem, Program..., p. 341; P. BalcareK, op. cit., p. 600; K.C. Felmy, op. cit., p. 43; M. Osterrieder, op. cit., p. 41; С. ЗОЛОТАРЕВ, op. cit., p. 300; М. ЧХЕНКЕЛИ, op. cit., p. 134.

${ }^{10}$ J. Meyendorff, L'iconographie..., p. 270; Т.А. Сидорова, op. cit., p. 222-223; Р. Balcareк, op. cit., p. 600; M.V. Marini Clarelli, op. cit., p. 58; A. Deyneka, op. cit., p. 34-35; С. ЗОлотарев, op. cit., p. 300.

${ }^{11}$ I.D. ŞтEFĂNescu, op. cit., p. 140-141; J. Meyendorff, L'iconographie..., p. 270; T.А. СиДОРовА, op. cit., p. 222; S. Der Nersessian, Program..., p. 341; Г.M. Прохоров, op. cit., p. 9; P. BalcareK, op. cit., p. 600; К.С. Felmy, op. cit., p. 43; Л.М. Евсеева, Пир Премудрости..., p. 194; М. OsterrieDER, op. cit., p. 41; С. ЗОЛОТАРЕВ, op. cit., p. 300; М. ЧХЕНКЕЛИ, op. cit., p. 134.

${ }^{12}$ J. Meyendorf, L'iconographie..., p. 270; T.A. Сидорова, op. cit., p. 222-223; S. Der Nersessian, Program..., p. 341; P. BALCAReK, op. cit., p. 600; M.V. MARIni Clarelli, op. cit., p. 58; L. LifŠIC, La Sapienza..., p. 59; Л.М. ЕвсеввА, Пир Премудрости..., р. 194; Л. Лифшиц, София Премудрость Божия..., p. 11; IDEM, Премудрость..., p. 142; M. OsterRIEDeR, op. cit., p. 41; С. ЗОЛОтАРев, op. cit., p. 300; М. ЧХЕНКЕЛИ, ор. cit., p. 134.
} 
A quite unusual development of the theme of Sophia's banquet is found on a painting which decorates the eastern wall of the narthex of the Church of the Entrance of the Holy Mother of God into the Temple, being a part of the Hilandar Monastery on Mount Athos ${ }^{13}$. Unfortunately, the original polychromy of the interior of the church, created most probably in $1320-1321^{14}$ underwent extensive "renovation" at the beginning of the $19^{\text {th }}$ century, as a result of which significant parts of the paintings lost their original form ${ }^{15}$. According to experts on the issue, the current iconographic scheme - illustrating Prov 9, 1-6 - can be considered with some degree of uncertainty as a monument dating from the $14^{\text {th }}$ century made at the behest of Stephen Uroš II Milutin of Serbia ${ }^{16}$.

In the Hilandar artefact there is a laid table, at which three winged figures feast. According to many researchers, one of them, located - as in the above-discussed painting of Ohrid - on the left side of the iconographic scheme, can be identified as the personification of Divine Wisdom ${ }^{17}$. She is sitting on the throne, supporting her feet on a footrest. She is enshrouded with sidelong robes: chiton and himation in contrasting colors. Using her left hand Sophia is reaching for a vessel located in front of her on the table. She seems to reach her hand out towards the other participants of the feast.

The most fascinating element of the depiction is the fact that personified Wisdom is shown here with three identical heads, surrounded by a joint rhomboid glory ${ }^{18}$. These types of image are very rare in Byzantine $\operatorname{art}^{19}$ and seem to suggest that the figure of Sophia should be recognized as the personification of all persons of the Trinity ${ }^{20}$. The Trinitarian connotations on the Hilandar iconographic scheme is also suggested by the two other figures accompanying the Divine Wisdom at the table. Looking at the painting, at first glance, three angels feasting together can

${ }^{13}$ J. Meyendorff, L'iconographie..., p. 272; Л.М. ЕвСевва, Две символические композиции..., p. 140; P. BalcareK, op. cit., p. 601; B. Todić, Serbian Medieval Painting. The Age of King Milutin, Belgrade 1999, p. 60, 83, 105, 153, 165, 198, 353-354; И.М. ЂорЂЕвић, op. cit., p. 196; С. ЗолотАРев, op. cit., p. 299-300.

${ }_{14}$ Л.М. ЕвсеввА, Две символические композиции..., p. 140; P. BALCAREк, op. cit., p. 601; B. Todić, op. cit., p. 353; И.М. ЂОРТЕВИТ, op. cit., p. 196; С. ЗОЛОТАРЕВ, op. cit., p. 300.

${ }^{15}$ S. der Nersessian, Program..., p. 341; Л.М. Евсеева, Две символические композиции..., p. 140;

P. BALCAReк, op. cit., p. 601; В. ТоDiĆ, op. cit., p. 60, 353; И.М. ЂОРЂЕвИЋ, op. cit., p. 196.

${ }_{16}$ Л.М. ЕвсеЕвА, Две символические композиции..., p. 140; И.М. ЂорЂевиТ, ор. cit., p. 196.

${ }^{17}$ A.M. Аmmann, op. cit., p. 145; S. Der Nersessian, Program..., p. 341; Л.М. Евсеeва, Две симвотические композиции..., p. 140; Р. ВацСаRек, ор. cit., р. 601; И.М. ЂОРЂЕВИЋ, ор. cit., p. 196.

${ }^{18}$ S. der Nersessian, Program..., p. 341; Л.М. Евсеева, Две символические композиции..., p. 140; P. BalCAReК, op. cit., p. 601; И.М. ЂОРТЕВИК, op. cit., p. 196.

${ }^{19}$ A.M. Ammann, op. cit., p. 145; J. Meyendorff, L'iconographie..., p. 272; Л.М. ЕвсеЕва, Две симвотические композиции..., p. 134-146; И.Ф. МейендорФ, Тема..., p. 246; IDEм, Wisdom-Sophia..., p. 394; Р. BALCAREK, op. cit., p. 601; В. Todić, op. cit., p. 60, 83, 105, 165, 351, 354; И.М. ЂОРЂЕВИЋ, op. cit., p. 196; С. ЗОЛОтАРев, op. cit., p. 299-300; M. MARTEns-CzARnecкA, The Wall Paintings from the Monastery on Kom H in Dongola, Warszawa 2011, p. 155-159.

20 Л.М. ЕвсеЕвА, Две символические композиции..., p. 140; Р. BALCARек, ор. cit., p. 601. 
be seen, which is a scene that can be easily associated with depictions of the Old Testament Trinity. However, in the discussed artefact some clear references to Prov $9,1-6$ can be found. Certainly, one of them is a richly decorated canopy put over the heads of the feasting persons, which is supported by seven pillars. The placing of the image of biblical King Solomon on the right side of the iconographic scheme seems to be of great importance ${ }^{21}$.

Almost at the same time, on the initiative of King Stephen Uroš II Milutin of Serbia, another monument of Serbian art was created, which contains a representation of personified Divine Wisdom, feasting in the house built by herself - it is a painting from 1321, which decorated the eastern wall of the altar in the Church of the Annunciation in the Gračanica Monastery ${ }^{22}$.

Sophia sits in the center of the iconographic scheme at the table on which there is only a parchment and writing material. She is covered with a purple robe without sleeves, which clearly emphasizes her bustline. Her head is uncovered and surrounded by a gold and circular glory. Behind her a pair of outstretched wings can be seen. In her left hand, as if in reference to the most archaic forms of sapiential iconography, the personified Wisdom holds a scroll of parchment, whereas in the right hand she holds a reed pen ${ }^{23}$.

Despite the relatively free treatment of the issue one cannot have any doubts that the painting is actually an illustration of a story from the ninth chapter of the Book of Proverbs. A lesible inscription, located in the upper part of the depiction informs us about it: пртн[үА]

\footnotetext{
${ }^{21}$ S. Der Nersessian, Program..., p. 341-342; Л.М. Евсеева, Две символические композиции..., p. 140. ${ }^{22}$ V.R. Petković, op. cit., p. VI, 53; A.M. Ammann, op. cit., p. 145; J. Meyendorff, L'iconographie..., p. 270, 273; S. RADojčić, La table..., p. 220; Л.М. ЕвсеЕвА, Две символические композиции..., p. 139; С. РАдојчић, О Трпези Премудрости..., р. 226; Г.М. Прохоров, ор. cit., р. 8; И.Ф. МейендорФ, Teмa..., p. 246; IDEM, Wisdom-Sophia..., p. 394; Б. Живковић, Грачаница. Цртежи фресака, Београд 1989, pl. VII; P. BALCAReK, op. cit., p. 600; K.C. Felmy, op. cit., p. 44; L. Lifšic, Die Ikone..., p. 31, 35; B. Todić, op. cit., p. 252, 330-331; IDEм, Грачаница. Сликарство, Приштина 1999, р. 80, 144; Л.М. ЕвСеЕвА, Пир Премудрости..., р. 194; Л. ЛиФшиц, Собия Премудрость Божия..., p. 10-11; Н. Пивоварова, Премудрость и Церковь..., р. 324; Л. ЛиФшиц, Премудрость..., p. 140; В.Г. БрюсовА, ор. cit., p. 61, 66; И.М. ЂОРЂЕвИЋ, ор. cit., p. 196; А. DеYNeКА, op. cit., p. 34; M. Gligorijević-Maksimović, Classical Elements in the Serbian Painting of the Fourteenth Century, ЗРВИ 44, 2007, p. 366; М. ТЕNACE, Le sens des représentations de la Sophia comme ange dans la tradition orthodoxe russe. Un pont entre teologie, philosophie et art, JEaCS 59, 2007, p. 267; V. Tsamakda, op. cit., p. 227; С. ЗОЛОТАРЕВ, op. cit., p. 299-300; Е.Б. ГРОМОВА, op. cit., p. 7; М. ЧХЕНКЕЛИ, op. cit., p. 136.

${ }^{23}$ I.D. ŞTEFĂNESCU, op. cit., p. 141; J. MeYENDORFF, L'iconographie..., p. 270; S. RADOJČIĆ, La table..., p. 221; IDEм, О Трпези Премудрости..., p. 227; Г.М. Прохоров, оp. cit., p. 9; P. BALCAReк, op. cit., p. 600; К.С. FеLмy, op. cit., p. 44; Б. Тодић, Грачаница..., p. 145; В.Г. БрюсовА, ор. cit., p. 66, 181; И.М. ЂОРЂЕвИћ, op. cit., p. 196; С. ЗолОТАРев, ор. cit., p. 300; Д. БОЈОвИћ, Трпеза Премудрости, Београд-Ниш 2009, p. 16, 65; Е.Б. ГромовА, ор. cit., p. 7; М. ЧХенкели, op. cit., p. 136.

${ }^{24}$ J. Meyendorff, L'iconographie..., p. 270-271; Р. BALCAReк, op. cit., p. 600; Б. Тодић, Грачаниu,a..., p. 80; М. TeNACE, op. cit., p. 267; В.Г. БрюСова, op. cit., p. 66; С. ЗОЛОтАРев, op. cit., p. 300; М. ЧХенКЕЛИ, op. cit., p. 136.
} 
the personified Wisdom is a portico with seven columns, which is a symbol clearly referring to the text of Prov 9, 1-6 $6^{25}$. In the painting there is also a place for the servants of Sophia: they approach from both sides the table, behind which sits their lady, and their silhouettes - like that of the iconographic scheme from Ohrid show the strong influence of ancient aesthetics. Yet, this time the creators of the considered artefact showed a remarkable inventiveness: the loose robes of both girls and musical instruments (tambourines?) in their hands make us guess they are dancers or musicians rather than regular servants ${ }^{26}$.

At this point it is worth noting one more element: the considered iconographic scheme, like the painting from the Hilandar Monastery discussed above, evokes in the viewer - through careful placement of characters - an association with the representations of the Old Testament Trinity. Interestingly, in the iconography of the interior of the Annunciation Church the image of three angels hosted by Abraham and Sarah was placed in a close proximity to the scene of Sophia's banquet ${ }^{27}$.

Unquestionably, the most developed form of the scheme can be found in the paintings - made in 1343-1348 - that decorate the vault of the chapel of St. Nicholas, which is part of the Serbian Visoki Dečani Monastery. It contains a group of four thematically related scenes, which are a very faithful illustration of the story of the ninth chapter of the Book of Proverbs ${ }^{28}$.

${ }^{25}$ J. Meyendorff, L'iconographie..., p. 270; S. Der Nersessian, Program..., p. 341; P. BalCarek, op. cit., p. 600; К.С. Felmy, op. cit., p. 44; Б. Тодић, Грачаница..., p. 145; Л.М. ЕвсеевА, Пир Премудроcти..., p. 194; В.Г. БРЮСОВА, op. cit., p. 66; С. ЗОЛОТАРЕВ, op. cit., p. 300; М. ЧХЕНКЕЛИ, op. cit., p. 136. ${ }^{26}$ I.D. ŞTEFĂnescu, op. cit., p. 141; J. MeyendorfF, L'iconographie..., p. 270; K.C. Felmy, op. cit., p. 44; Б. Тодић, Грачаница..., p. 207; С. ЗОлотАРев, ор. cit., p. 300.

${ }^{27}$ S. RAdojčić, La table..., p. 220-221; IDEM, O Трпези Премудрости ..., p. 226-227; K.C. Felmy, op. cit., p. 44; B. Todić, Serbian Medieval Painting..., p. 154, 250, 331; IDEм, Грачаница..., p. 144, 194-195; И.М. ЂОРЂЕвИЋ, op. cit., p. 196; М. ЧХенкЕлИ, op. cit., p. 136.

${ }^{28}$ V.R. PetKović, op. cit., p. VII, 98; I.D. ŞTEFĂnescu, op. cit., p. 141; A.M. AMmann, op. cit., p. 145; J. Meyendorff, L'iconographie..., p. 271; С. РАдојчић, Старо српско сликарство, Београд 1966, p. 136; IDEM, La table..., p. 221; Т.А. СИДОРОВА, op. cit., p. 222-223; Л. ПрАшКОВ, op. cit., p. 155; Л.М. ЕвсеЕва, Две символические композиции..., р. 139; С. РАДојчић, О Трпези Премудрости..., p. 227; IDEM, Улога антике у старом српском сликарству, [in:] IDEM, Одабрани члании и студије..., p. 71; Г.М. Прохоров, ор. cit., p. 8; И.Ф. МейендорФ, Тема..., p. 246; IDEм, Wisdom -Sophia..., p. 394; B. Todić, Tradition et innovations dans le programme et l'iconographie des fresques de Dečani, [in:] Dečani et l'art Byzantin au milieu du XIVe siecle. A l'occasion de la celebration de 650 ans du monastere de Dečani. Septembre 1985, ed. V.J. Djurić, Beograd 1989, p. 258-259; P. BALCAReK, op. cit., p. 600-601; K.C. Felmy, op. cit., p. 44; L. LifŠic, Die Ikone..., p. 31; Л.M. Евсеeba, Пир Премудрости..., р. 194; Л. Лифшиц, Премудрость..., p. 140; В.Г. БрюсовА, ор. cit., p. 67; И.М. ЂОРЂЕвић, ор. cit., p. 196; М. ГлиГОРИјЕвиТ-МАКСИМОвић, Иконографија Богородичиних праобраза у српском сликарству од средине XIV до средине XV века, ЗРВИ 43, 2006, p. 286, 300; A. Deyneka, op. cit., p. 34; M. Gligorijević-Maksimović, Classical Elements..., p. 366; V. TsaMAKDA, op. cit., p. 227; С. ЗОЛОТАРЕВ, op. cit., p. 299-300; Д. БОЈОВИЋ, op. cit., p. 68; Е.Б. ГРОМОВА, op. cit., p. 7; М. ЧХенкЕЛИ, op. cit., p. 134. 
In the painting, located in the western part of the vault, there is Lady Wisdom sitting on a throne next to a table laid for a feast. The image refers to the representation of Sophia, common in $14^{\text {th }}$-century Serbian painting: she is covered with a pink chiton, trimmed with a gold ribbon around the neck and a green himation. The head is uncovered and adorned with a glory composed of two figures - a golden circle, behind which the contours of a rhombus are visible. Behind Sophia there is a pair of wings. The personified Wisdom holds in her left hand a scroll of parchment and she puts her right hand up. In the background there is a building, which is certainly a representation of the house of Sophia. In the upper part of the scheme there is a quote from Prov 9, 1 (Wisdom hath built herself a house, she hath hewn her out seven pillars ${ }^{29}$.

In the northern part of the vault there is a painting that illustrates Prov 9, 3-4 (She hath sent her maids to invite to the tower and to the walls of the city: Whosoever is a little one, let him come to me!). Again there is a generously laid table and behind it are two winged figures, most probably - the images of the maids of the Lady Wisdom. The figure on the left holds in her hands a loaf of bread and her companion holds up a cup of wine ${ }^{30}$. The interpretational context is thus extended by clear connotations of the Eucharist ${ }^{31}$. The third scene, located in the eastern part of the vault, is worst-preserved. In the center there is a table with a purple canopy on it. The figure represented on the left side of the painting can be interpreted - by analogy with the above discussed depictions of Ohrid and the Hilandar Monastery - as the image of the personification of Divine Wisdom inviting people who want to accompany her to the feast. The representation was likely accompanied by a quote from Proverbs 9, 5 (Come, eat my bread) ${ }^{32}$.

In the last southern part there is a scheme based on the painted representations of the scene of the Communion of the Apostles. The winged figure located on the left side of the painting can probably be regarded as an image of Sophia, taking into account the fact that the figure is covered with identical robes as the personification

\footnotetext{
${ }^{29}$ I.D. Ştefănescu, op. cit., p. 141; J. Meyendorff, L’iconographie..., p. 271-272; S. Der NerSessian, Program..., p. 341; В. Todić, Tradition..., p. 259; Л.М. Евсеева, Пир Премудрости..., p. 194-195; И.М. ЂорЂЕвић, ор. cit., р. 196; М. ГлигоРијевић-МАКсимовић, Иконографија..., p. 285; С. ЗОЛОТАРЕВ, op. cit., p. 300; М. ЧХЕНКЕЛИ, op. cit., p. 134-135.

${ }^{30}$ J. Meyendorff, L'iconographie..., p. 272; В. Todić, Tradition..., p. 259; Л.М. Евсеeва, Пир Премудрости..., p. 195; М. ГлиГоРијЕвић-МАКСимовић, Иконографија..., р. 285; С. ЗоЛОтАРев, op. cit., p. 300-301; B. Cvet ković, Some Hierotopical Aspects of the New Jerusalem Programmes in the Fifteenth-century Serbia, [in:] Новые Иерусалимы. Иеротопия и иконография сакральных пространств, еd. А.М. Лидов, Москва 2009, р. 618, 631; М. Чхенкели, ор. cit., p. 135-136.

${ }^{31}$ I.D. ŞTefăNescu, op. cit., p. 141; J. MeyendorfF, L'iconographie..., p. 272; B. Todić, Tradition..., p. 259; P. BalCareK, op. cit., p. 601; К.С. FеLmy, op. cit., p. 44; Л.М. ЕвСеЕвА, Пир Премудрости..., p. 194-195; С. ЗОЛОТАРЕВ, op. cit., p. 301; М. ЧХЕНКЕЛИ, op. cit., p. 135.

32 J. Meyendorff, L’iconographie..., p. 272; В. Todić, Tradition..., p. 259; М. ГлигоријевитМАКСИМОвић, Иконограбија..., p. 285; С. ЗОЛОТАРЕв, ор. cit., p. 301; М. ЧХеНКЕЛИ, ор. cit., p. 135.
} 
of Divine Wisdom in the first scene of the group. She leans in the direction of an imaginary group of people next to her, giving a cup of wine to the man standing closest to her. In the upper part of the depiction there is an inscription taken from Prov 9, 5 (drink the wine which I have mingled for you!) ${ }^{33}$.

The tendency to depict Divine Wisdom in the form of a young woman, dressed in costume based on the ancient Greek fashion, spread in the land of Eastern Slavs in the second half of the $14^{\text {th }}$ century. At the end of the century the first attempts to develop the story in terms of iconography, originating from the ninth chapter of the Book of Proverbs, appeared in the Russian art. Perhaps the oldest known example of the illustration of Prov 9, 1-6, coming from Russia, is a miniature, located in the lower right corner of the $63^{\text {rd }}$ card of the Kiev Psalter (1397, РНБ, ОЛДП f. 6) right next to the text of Psalm $45^{34}$. There is a small-sized figure, represented inside a building with three domes with a cross. Putting both hands up, it seems to support the ceiling of the building. Its head is uncovered and surrounded by a circular, golden glory. Behind this there is a pair of outstretched wings ${ }^{35}$. It is also worth nothing that the figure is covered with an unusual kind of robes. They do not resemble - which one would expect given the means of representing Sophia in South Slavic painting - an ancient female chiton, evoking associations with the official regal costume (purple robes with a gold sash and dark red shoes) ${ }^{36}$. The image seems to anticipate certain elements of the representation of Divine Wisdom, typical of the art of Novgorod the Great in the $15^{\text {th }}$ and $16^{\text {th }}$ centuries. In the upper part there is an inscription, which leaves no doubts of the identity

\footnotetext{
${ }^{33}$ J. Meyendorff, L'iconographie..., p. 272-273; S. Der Nersessian, Note..., p. 215; Т.А. Сидорова, op. cit., p. 223; Г.М. Прохоров, op. cit., p. 9; В. Todić, Tradition..., p. 259; K.C. Felmy, op. cit., p. 44; Л.М. ЕвСеЕвА, Пир Премудрости..., p. 195; Л. ЛИФшиц, Премудрость ..., p. 140; М. ГлиГоРијЕвићМАКСИмовић, Иконографија..., р. 286; С. ЗолотАРев, ор. cit., р. 301; Д. Бојовић, ор. cit., р. 68; М. ЧХенКЕлИ, op. cit., p. 135-136.

${ }^{34}$ Киевская Псалтирь 1397 года из Государственной Публичной Библиотеки имени М.Е. Салтыккова-Щедрина в Ленинграде [ОЛДП F 6], ed. Т.В. ЮровА, Москва 1978, fol. 63; А.М. АмMANN, op. cit., p. 144; В.Н. ЛАЗАРев, Мозаики Софии Киевской, Москва 1960, p. 20; Г.И. ВздорНов, Исследование о Киевской Псалтири, Москва 1978, р. 64, 118; IDEм, Искусство книги в Древней Руси. Рукописная книга Северо-Восточной Руси ХII-начала XV вв., Москва 1980, p. 49; И.Ф. МейендоРФ, Тема..., p. 246; IDEм, Wisdom-Sophia..., p. 394; F. von Lilienfeld, "Frau Weisheit" - in Byzantinischen und Karolingischen Quellen des 9. Jahrhunderts - allegorische Personifikation, Hypostase oder Typos?, [in:] EAdem, Sophia - die Weisheit Gottes. Gesammelte Aufsätze 1983-1995, Erlangen 1997, p. 129; Г.В. Флоровский, О почитании Собии, Премудрости Божией, в Византии и на Руси, [in:] Догмат и история, Москва 1998, p. 394-414; P. BAlсаRек, op. cit., p. 596; M. Osterrieder, op. cit., p. 46; В.Г. БРЮсовА, op. cit., p. 8, 69, 71, 182; A. DeyneKA, op. cit., p. 6, 63; С. ЗОЛОТАРЕВ, op. cit., p. 250, 292.

${ }^{35}$ Г.И. ВЗдорнов, Исстедование..., p. 118; J. MeYendorf, Wisdom-Sophia..., p. 394; F. von LiliENFELD, op. cit., p. 129; Р. BALCAREK, op. cit., p. 596; В.Г. БрЮСОВА, op. cit., p. 69, 182; С. ЗОЛОТАРЕВ, op. cit., p. 250.

${ }^{36}$ F. vON LILIENFELD, op. cit., p. 129.
} 
of the figure, shown in the miniature: $\overrightarrow{\mathbf{c}} \mathbf{т}$ ая $\operatorname{co} \phi \mathbf{a d}^{37}$. Experts are inclined to assume that the work contains a representation of the personification of Divine Wisdom, building a house for herself ${ }^{38}$.

It is much harder, however, to give a definitive answer to the question why the depiction, referring to Prov 9, 1-6, was included by the creators of the Kiev Psalter in the form of illustrations to the text of Psalm 45. As emphasized by the researcher of the manuscript, G.I. Vzdornov, it is an unprecedented representation. In none of the preserved Byzantine and Slavic Psalters is there an image referring to the story of the ninth chapter of the Book of Proverbs ${ }^{39}$. Furthermore, the miniature, which adorns the $63^{\text {rd }}$ card of the manuscript, does not show any convergence in style and composition with the scenes of Sophia's banquet, known from $14^{\text {th }}$-century Serbian fresco painting. The only other artefact that could - with some degree of uncertainty - be considered a source of inspiration for the creators of this painting is a headpiece, which adorns one of the cards of Branko Mladenović Psalter, created in 1346 (currently kept at the National Library in Bucharest).

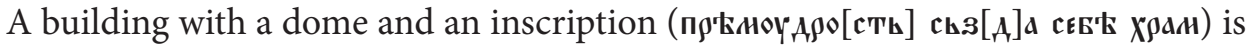
represented on $\mathrm{it}^{40}$.

The representation of the scene of Sophia's banquet, which certainly served as a model for other later depictions of this type, known from the Eastern Slavs, seems to be a painting from the church of the Dormition of the Mother of God in Volotovo ${ }^{41}$. It was completely destroyed during World War II. The examination

\footnotetext{
${ }^{37}$ A.M. Ammann, op. cit., p. 144; Г.И. Вздорнов, Исследование..., p. 64, 118; F. von LiLienfeld, op. cit., p. 129; P. BALCAReK, op. cit., p. 596; M. OsterRieder, op. cit., p. 46; В.Г. БРЮСова, op. cit., p. 69; A. DeYneKa, op. cit., p. 6; С. ЗОЛОтАРев, op. cit., p. 250.

${ }^{38}$ Г.И. Вздорнов, Исследование.., р. 118.

${ }^{39}$ Ibidem, p. 64, 118.

${ }^{40}$ S. Radojčić, La table..., p. 219; Г.И. Вздорнов, Исследование..., p. 64; С. РАдојчић, О Трпези Премудрости..., p. 225; В.Г. БрюсовА, ор. сit., р. 70.

${ }^{41}$ J. Meyendorff, L’iconographie..., p. 272, 274; Т.А. СидоровА, op. cit., p. 212, 214; М.В. АлПатов, Фрески иеркви Успения на Волотовом Поле, Москва 1977, p. 18-19, pl. 12; А.И. ЯковлевА, “Образ мира" в иконе "Собия Премудрость Божия", [in:] Древнерусское искусство. Проблемы и атрибуции, еd. В.Н. ЛАЗАРев, О.И. ПоДОБЕДОВА, Москва 1977, р. 395; Э.С. СмИРНОвА, Миниатюры двух новгородских рукописей, [in:] Древнерусское искусство. Рукописная книга, Москва 1983, p. 188; Г.М. Прохоров, ор. cit., р. 9; И.Ф. МейендоРФ, Тема..., p. 246; IDEм, Wisdom-Sophia..., p. 394; D.F. Fiene, op. cit., p. 454; Г.И. Вздорнов, Волотово. Фрески иеркви Успения на Волотовом поле близ Новгорода, Москва 1989, р. 57; P. BAlCAReк, ор. cit., p. 601; K.С. Felmy, op. cit., p. 60; L. LifšIC, Die Ikone ..., p. 31-32; Л.М. ЕвсеЕвА, Пир Премудрости..., p. 196; Л. Лифшиц, София Премудрость Божия..., р. 11; Н. ПивоваровА, Премудрость и Церковь..., р. 324; Л. Лифшиц, Премудрость..., p. 142; М.Н. Громов, ор. сit., p. 57; Т.В. ВолодинА, Культура региона: художественная культура Великого Новгорода. Избранные страницы, Великий Новгород 2002, р. 27; В.Г. Брюсова, op. cit., p. 76, 80; А. Deyneка, op. cit., p. 34; P. Hunt, Confronting the End. The Interpretation of the Last Judgment in a Novgorod Wisdom Icon, Bsl 65, 2007, p. 282; A. SulikowsKA-GĄsKa, Spory o ikony na Rusi w XV i XVI w., Warszawa 2007, p. 261; В. Пуцко, Резная деревянная икона пинского князя, ГБ 23, 2008; С. ЗОЛОтАРев, op. cit., p. 300; Е.Б. ГромовА, op. cit., p. 13. The
} 
of the polychromy, which adorns its interior - made most likely in the 80-90s - must therefore be carried out on the basis of photographs and drawings, prepared in the first quarter of the $20^{\text {th }}$ century ${ }^{42}$.

The painting had the form of an elongated rectangle $e^{43}$. In the lower left corner there are the contours of a table, on which, however - in contrast to the abovediscussed Balkan iconographic schemes - there is nothing ${ }^{44}$. Above it, as if in the background, there is a building, which resembles an ancient Greek sanctuary supported by seven pillars ${ }^{45}$. On its roof, in the upper left corner of the painting there is a figure holding in its left hand an unfolded parchment. The inscription on it

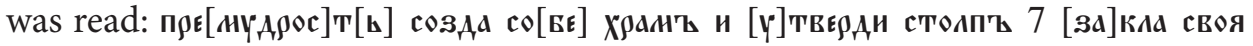

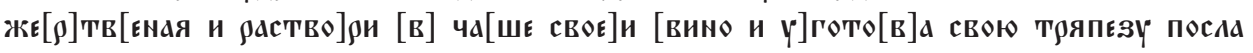
$\mathfrak{c в о [ \varepsilon г о ] ~} \mathrm{\rho aza}^{46}$. The above-mentioned quote can be identified as being from the Book of Proverbs 9, 1-3 ${ }^{47}$. It is much more difficult to interpret the depicted figure next to the inscription. Perhaps it is an image of biblical King Solomon who, in the Middle Ages, was considered the author of the Book of Proverbs ${ }^{48}$. A further part of the scheme contains a depiction of Divine Wisdom sitting on a throne with her back to the viewer. Sophia is covered with regal robes as was the case in the miniature from the Kiev Psalter and on later icons from the Novgorod the Great. In one

idea of T.A. Sidorova, who assumed that the inclusion of the Sophia's banquet in the interior of the church in Volotovo was intended to oppose the Novgorod heresy of the strigolniks, has been rejected by the scholars; Т.А. СидоровА, ор. cit., p. 228-231; Г.И. Вздорнов, Волотово..., p. 66-67; P. BALCAREK, op. cit., p. 602.

${ }^{42}$ Г.И. ВЗДОРНОв, Волотово..., pl. 181; С. ЗОлОтАРЕВ, ор. cit., p. 301. In the interior of the church in Volotovo conservation works are being carried out to restore the greatest possible part (50-80\%) of the original polychrome of the temple. The project is carried out in the Laboratory of Scientific Restoration Freska in Novgorod the Great under the direction of Tamara I. Anisimova. The scene of Sophia's banquet, which was originally located on the barrel vault of the narthex of the church, has not been reconstructed yet, but there is a chance that conservators who work on the painting will manage to restore it to its correct state in the near future.

${ }^{43}$ Т.А. СидоровА, ор. cit., р. 214; Г.И. Вздорнов, Волотово..., pl. 181.

${ }^{44}$ Т.А. СИДоРОвА, ор. cit., p. 215; Г.И. ВЗДОРНов, Волотово..., pl. 181; Р. ВАLСARек, op. cit., p. 602; Л.М. ЕвсеЕвА, Пир Премудрости..., р. 196; Л. Лифшиц, Собия Премудрость Божия..., р. 11; IDEM, Премудрость..., p. 142; С. ЗОЛОТАРЕв, op. cit., p. 301; Е.Б. ГРОМОвА, op. cit., p. 20.

45 Т.А. СидОРОвА, ор. cit., p. 215; А.И. ЯКОвЛЕвА, ор. cit., p. 396; Г.И. ВЗдОРНОВ, Волотово..., pl. 181; P. BalcareK, op. cit., p. 602; Л.М. ЕвсеЕва, Пир Премудрости..., p. 196; Л. ЛиФшиц, Собия Премудрость Божия..., p. 11; IDEм, Премудрость..., p. 142; В.Г. БРюсовА, ор. cit., p. 77; С. ЗолотА Рев, op. cit., p. 301; Е.Б. ГромовА, op. cit., p. 20; P. Hunt, The Wisdom Iconography..., p. 104. ${ }^{46}$ Г.И. Вздорнов, Волотово..., pl. 181.

${ }^{47}$ К.С. Fецму, op. cit., p. 60; Л.М. ЕвСеЕВА, Пир Премудрости..., p. 196; В.Г. БРюСОВА, op. cit., p. 78. ${ }^{48}$ Т.А. СидоровА, ор. cit., p. 215; А.И. ЯковлевА, оp. cit., p. 396; Г.И. ВздорНов, Волотово..., pl. 181; P. BalCareK, op. cit., p. 602; К.С. Felmy, op. cit., p. 60; Л.М. ЕвСеЕва, Пир Премудрости..., p. 196; В.Г. БрюСОВА, op. cit., p. 78, 182; С. ЗОЛОТАРЕВ, op. cit., p. 301. 
hand she holds a long sceptre. Her head is surrounded by a poorly preserved glory, which most probably originally had the shape of two overlapping rhombuses ${ }^{49}$.

On the right side of the Divine Wisdom one can see the barely noticeable figures of her three servants, who (as in the Book of Proverbs) kill animals for the feast ${ }^{50}$. Above them there is a figure of an old man holding a scroll in his hands. Unfortunately the inscription on it did not survive into the beginning of the $20^{\text {th }}$ century ${ }^{51}$.

In the central part of the work there is a scene which resembles a representation from the Visoki Dečani Monastery: a group of servants give cups of wine to the people ${ }^{52}$. To the right of them there is another male figure who holds a scroll in his hand, with a fairly well-preserved inscription:

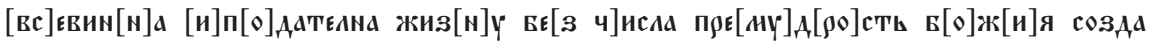

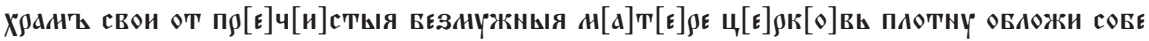

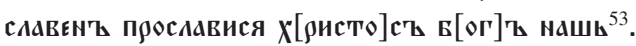

It is not difficult to note that this is a quote from one of the troparions from the first stanza of the canon of the Matins of Holy Thursday by Cosmas of Maiuma, in which the process of building a house by Divine Wisdom is compared to the act of Christ's incarnation in the human form through the Virgin Mary ${ }^{54}$. In this context it seems quite probable that the two male figures, represented on the painting are, as it has been suggested in the literature, the images of those Byzantine hymnographers of the $8^{\text {th }}$ century to whom Eastern Christian liturgical

${ }^{49}$ Т.А. СиДОРовА, op. cit., p. 214-215; А.И. ЯковЛЕвА, ор. cit., p. 396; Л.М. ЕвсеЕвА, Две символические композиции..., p. 139; Г.М. Прохоров, ор. cit., p. 9; Г.И. Вздорнов, Волотово..., pl. 181; P. BalcareK, op. cit., p. 602; К.С. FelmY, op. cit., p. 60; Л.М. ЕвсеевА, Пир Премудрости..., p. 196; Л. ЛиФшиц, Собия Премудрость Божия..., р. 11; IDEм, Премудрость.., р. 142; В.Г. БрЮсовА, op. cit., p. 77-78, 182; С. ЗОЛОТАРЕВ, op. cit., p. 301; В. ПуцКО, op. cit.; Е.Б. ГРОМОВА, op. cit., p. 7, 13, 20; P. Hunt, The Wisdom Iconography..., p. 103-104.

${ }^{50}$ Т.А. СидОРОвА, op. cit., p. 215; Г.М. ПрохоРов, ор. cit., p. 10; Г.И. ВздОРНОв, Волотово..., pl. 181; P. Balcareк, op. cit., p. 602; Л.М. ЕвсеЕва, Пир Премудрости..., p. 196; Л. ЛИФшиц, Собия Премудрость Божия..., p. 11; В.Г. БрюсовА, op. cit., p. 78, 182; С. ЗОЛОтАРев, op. cit., p. 301; В. ПуцКО, op. cit.; Е.Б. ГромовА, op. cit., p. 7, 20.

${ }^{51}$ Т.А. СИДОРОвА, ор. cit., p. 215; Г.И. ВздОРНОв, Волотово..., pl. 181; Р. ВALCARек, op. cit., p. 602; K.С. FеLMY, op. cit., p. 60; С. ЗОЛОТАРЕВ, op. cit., p. 301.

52 Т.А. СидоровА, op. cit., p. 215; А.И. ЯковлевА, op. cit., p. 396; Г.М. Прохоров, op. cit., p. 10; Г.И. Вздорнов, Волотово..., pl. 181; Л.М. ЕвсеЕвА, Пир Премудрости.., р. 196; Л. Лифшиц, Собия Премудрость Божия..., p. 11; В.Г. БрюсовА, ор. сit., p. 78; С. ЗОЛОтАРев, ор. cit., p. 301; В. Пуцко, op. cit.; Е.Б. ГромовА, op. cit., p. 7, 20; P. Hunt, The Wisdom Iconography..., p. 103-104.

${ }^{53}$ Г.И. Вздорнов, Волотово..., pl. 181.

${ }^{54}$ А.И. ЯковлЕвА, ор. cit., p. 396; Г.И. ВздОРНОв, Волотово..., pl. 181; Р. ВАLCARек, op. cit., p. 603; К.С. Fеlмy, ор. cit., p. 60; Л.М. ЕвСЕеВА, Пир Премудрости ..., p. 196; В.Г. БрЮСОВА, ор. cit., p. 78; A. DeYneKa, op. cit., p. 34; Е.Б. Громова, op. cit., p. 20; P. Hunt, The Wisdom Iconography ..., p. 104. 
poetry owes the most important works devoted to Sophia: Cosmas of Maiuma and his half-brother, John of Damascus, the author of the Canon of Pascha ${ }^{55}$.

On the right edge there is - as if in reference to the text of the canon of the Matins of Holy Thursday - an image of the Virgin and Child. The intention of the anonymous artist is quite clear: the house of Sophia on the left side, a representation of a person, who in the hymnography of the Eastern Church was associated with it on the right one ${ }^{56}$.

The painting from the church of the Dormition of the Mother of God in Volotovo is probably the oldest known attempt at the development of that motif of the Sophia's banquet in terms of iconography, coming from the East Slavs. In the discussed depiction there are references to the earlier iconographic schemes of this kind, emerging in the Balkans in the $13^{\text {th }}$ and $14^{\text {th }}$ centuries as well as some innovative elements, which in time would become typical of Russian representations, illustrating the story from the ninth chapter of the Book of Proverbs.

The most representative example of the East Slavic variant of the discussed iconographic scheme is the icon that was originally created for the church of the monastery of St. Cyril located in the vicinity of Novgorod the Great ${ }^{57}$. This artefact, dated to the end of the $15^{\text {th }}$ century ${ }^{58}$ or the first half of the $16^{\text {th }}$ century (up to $1548)^{59}$, is now located in the collection of the Tretyakov Gallery in Moscow

55 Т.А. СидОРОвА, ор. cit., p. 223; А.И. ЯкОвлЕвА, op. cit., p. 396; Г.И. ВздОРНОВ, Волотово..., p. 58, pl. 181; P. BalcareK, op. cit., p. 603; K.С. Felmy, op. cit., p. 60; В.Г. БрюСовА, op. cit., p. 78, 182; В.Д. САРАБьяНОВ, Э.С. СмИРНОВА, История древнерусской Живописи, Москва 2007, р. 312-313; С. ЗОЛОтАРев, op. cit., p. 302; Е.Б. ГромовА, op. cit., p. 20; P. Hunt, The Wisdom Iconography..., p. 104. ${ }^{56}$ Т.А. СИДОРОвА, ор. cit., p. 215; А.И. ЯКОвЛЕвА, ор. cit., p. 396; Г.И. ВздОРНОВ, Волотово..., pl. 181; Р. BALCARек, ор. cit., p. 602; Л.М. ЕвСеЕВА, Пир Премудрости..., p. 196; Т.В. ВоЛОДИНА, ор. cit., p. 27; В.Г. БрЮСОВА, ор. cit., р. 78, 182; В.Д. САРАБьяНОВ, Э.С. СМИРНОВА, оp. cit., p. 312-313; С. ЗОЛОтАРев, op. cit., p. 301; Е.Б. ГРОМОвА, op. cit., p. 7, 20; P. Hunt, The Wisdom Iconography..., p. 104. ${ }^{57}$ T.A. Сидорова, op. cit., p. 212; D. Likнасноv, V. Laurina, V. PushкARIov, Novgorod Icons $12^{\text {th }}$ $17^{\text {th }}$ century, Leningrad 1980, pl. 205-206; D. LikhaCHov, Novgorod. Art Treasures and Architectural Monuments $11^{\text {th }}-18^{\text {th }}$ centuries. Architecture. Frescoes. Archeological Artefacts. Minor Arts. Icons. Illuminated MSS, Leningrad 1984, pl. 196; Г.М. Прохоров, op. cit., p. 12-13; K.C. FeLmY, op. cit., p. 53; Л.М. ЕвсеЕвА, Пир Премудрости..., р. 196; М.Н. Громов, ор. cit., р. 57; В.Г. БрюСовА, ор. cit., p. 90, 183; Р. Нunt, Confronting the End..., p. 281; В.Д. САРАБьянов, Э.С. СмиРнОВА, op. cit., p. 590; В. Пуцко, op. cit.; A. Tradigo, Ikony i święci prawosławni, trans. E. Maciszewska, Warszawa 2011, p. 45.

${ }^{58}$ J. Meyendorff, L'iconographie..., p. 274; М.Н. Громов, op. cit., p. 53; P. Hunt, Confronting the End..., p. 281; С. ЗОЛОтАРев, op. cit., p. 303.

${ }^{59}$ J. Meyendorff, L'iconographie..., p. 274; D. Likhachov, V. Laurina, V. Pushkariov, op. cit., pl. 205-206; D. LiкhaChov, op. cit., pl. 196; Г.М. Прохоров, op. cit., p. 12-13; Д.С. Лихачев, Г.К. ВАГнеР, Г.И. ВздорНов, Р.Г. Скрынников, Великая Русь. История и художественная кульmyра X-XVII в., Москва 1994, p. 360, 371; К.С. Fецмy, op. cit., p. 53; Л.М. ЕвсеевА, Пир Премyдрости..., p. 196; В.Г. БРЮСОВА, op. cit., p. 95; А. DеYNeKА, op. cit., p. 35; В.Д. САРАБЬЯНОВ, Э.С. Смирнова, op. cit., p. 590; В. Пуцко, op. cit.; С. Золотарев, op. cit., p. 302; A. Tradigo, op. cit., p. 45. 
(inventory № 28830$)^{60}$. The icon - like many other $16^{\text {th }}$ century Russian sacral paintings - is a well-developed image in terms of composition ${ }^{61}$. The scene of the feast, laid by Lady Wisdom is included. The figure of Sophia is located on the left side of the depiction - just as it is in the painting in the church of the Mother of God Peribleptos in Ohrid, in the Hilandar Monastery or the church in Volotovo. Her image was agreed with the typical sapiential iconography, which was already widespread in that period in Russia - like the ancient representation of muses. Sophia is wearing a white chiton, which uncovers the shoulders and clearly emphasizes the bustline. It is worth noting the windswept robes shown in almost the same way as in miniatures adorning Russian Gospels of the $15^{\text {th }}$ and $16^{\text {th }}$ centuries (e.g. МГУ, $2 \mathrm{Bg}$ 42; РГБ, ф. 247, Рогожск. № 138 ; БАН, 13.1.26). The head of Sophia is uncovered and surrounded by a glory, consisting of two rhombuses in red and green. The Divine Wisdom sits on a throne, supported by seven pillars. In her right hand she holds a long sceptre and in her left she holds the Eucharistic chalice ${ }^{62}$.

Interestingly enough, the figure of Sophia is surrounded by an extensive mandorla, consisting of several concentric circles. Perhaps the introduction of the element to the depiction should be explained as a reference to the theological concepts of Pseudo-Dionysius the Areopagite. It may be suggested by the placement of angelic figures in the two outer circles, described in the pages of the Celestial Hierarchy: seraphim, cherubim, thrones (first-sphere angels, which are closest to the Creator) in the red field and the angels of lower orders in the green and brown circle, which is most distant from Divine Wisdom ${ }^{63}$. It cannot also be excluded that it is an attempt of iconographic representation of the most important themes of the theology of Gregory Palamas. The circles directly surrounding Sophia are almost completely black, which can be interpreted as a reflection of the image of the unsearchable nature of God. Angels located in further spheres (red and green) would, in this context, be the personification of God's uncreated energies ${ }^{64}$.

${ }^{60}$ T.A. Сидорова, op. cit., p. 212; D. Likhachov, V. Laurina, V. Pushkariov, op. cit., pl. 205-206; D. Liкнасноv, op. cit., pl. 196; Г.М. ПрохоРОв, op. cit., p. 13; Д.С. ЛИХАЧЕВ, Г.К. ВАГНеР, Г.И. ВздОРНОВ, Р.Г. СКРЫНников, ор. cit., p. 360, 371; К.С. Fеlмy, op. cit., p. 53; М.Н. Громов, op. cit., p. 57; В.Г. БРюСОВА, op. cit., p. 95; Р. Нunt, Confronting the End..., p. 281; В.Д. САРАБЬяНОВ, Э.С. Смирнова, ор. cit., p. 590; В. Пуцко, ор. cit.; С. Золотарев, op. cit., p. 303; A. Tradigo, op. cit., p. 45.

${ }^{61}$ В.Д. САРАБьяНОв, Э.С. СмИРНОвА, op. cit., p. 594-595; A. SulikowsKa-GĄSKA, op. cit., p. 10.

${ }^{62}$ J. Meyendorff, L'iconographie..., p. 274; T.А. Сидорова, op. cit., p. 213; К.С. Felmy, op. cit., p. 54, 56; L. Lifšıc, La Sapienza..., p. 64; Л.М. ЕвсеевА, Пир Премудрости..., p. 196; Л. Лифшиц, София Премудрость Божия..., p. 16; IDEм, Премудрость..., p. 146; М.Н. Громов, ор. cit., p. 57; Е.Б. ГромовА, op. cit., p. 13; В.Г. БрЮСОвА, op. cit., p. 90-91; Р. HunT, Confronting the End..., p. 282-283; В. Пуцко, op. cit.; A. Tradigo, op. cit., p. 45.

${ }_{63}$ Т.А. СидоровА, ор. cit., p. 213; Г.М. Прохоров, op. cit., p. 13, 15; К.С. FеLмY, op. cit., p. 56; Л.М. ЕвСеЕвА, Пир Премудрости..., р. 196.

${ }^{64}$ A. Tradigo, op. cit., p. 45. 
The icon is, above all, a faithful illustration of the text of Prov 9, 1-6. Next to the figure of Sophia there is a table laid for a feast, at which her servants are bustling about. One of them pours wine from the amphorae in the ground into pots and cups. Behind him two other men kill calves which are to be eaten during the feast ${ }^{65}$. In the background there are seven servants of Divine Wisdom, giving out - in the same way as on the Volotovo painting - cups of wine to people ${ }^{66}$.

There are also three other figures that appear in the same context on a wall painting in the church of the Dormition of the Mother of God in Volotovo. On the right side there is a figure of the Virgin and Child in an identical mandorla as Sophia. The glory consists of several concentric circles, the last of which, the most external one, includes red figures of seraphim and cherubim ${ }^{67}$. On the back facade of the building there appears a male figure, depicted in regal purple robes and a gold crown. It can be identified as King Solomon. He holds in his left hand a scroll with a quote from Prov 9, $1^{68}$. At the foot of the Mother of God is another figure of a saint. His attire (dark brown cloak and white turban on his head) seems to suggest that it is a portrait of John Damascene ${ }^{69}$. However, a different interpretation can be adopted if one takes into account the text located on the scroll the saint holds (всевин[н]ал и жив[о]тог

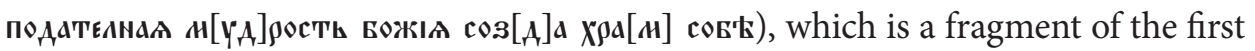
stanza of the canon of the Matins of Holy Thursday by Cosmas of Maiuma ${ }^{70}$.

In the upper part of the icon there is a representation of the house of Lady Wisdom. It was given the form of large six-pillar basilica with seven domes (six maller and one central) $)^{71}$. Below there is a depiction of seven ecumenical councils.

${ }^{65}$ Т.А. СидоровА, op. cit., p. 213-214; В. Пуцко, op. cit.

${ }^{66}$ Т.А. Сидорова, ор. cit., p. 213; М.Н. Громов, оp. cit., p. 57; P. Hunt, Confronting the End..., p. 284; В. ПуцКо, op. cit.; A. TRAdigo, op. cit., p. 45.

${ }^{67}$ J. Meyendorff, L'iconographie..., p. 274; Т.А. СидоровА, op. cit., p. 213; Г.М. Прохоров, op. cit., p. 12-13; K.C. Felmy, op. cit., p. 58; М.Н. ГРОмОВ, op. cit., p. 57; Е.Б. ГРОмОвА, op. cit., p. 13; В.Г. Брюсова, op. cit., p. 92; А. DeyneKa, op. cit., p. 35; P. Hunt, Confronting the End..., p. 284, 287; В. Пуцко, op. cit.; A. Tradigo, op. cit., p. 45.

${ }^{68} \mathrm{~J}$. Meyendorff, L'iconographie..., p. 274; Т.А. СидоровА, ор. cit., p. 213; В.Г. БрюсовА, Толкование на IX Притчу Соломона в Изборнике 1073 г., [in:] Изборник Святослава 1073 г. Сборник cтатей, ed. Б.А. РЫБАКов, Москва 1977, p. 300; Г.М. Прохоров, ор. cit., p. 13; К.С. Felmy, op. cit., p. 56; М.Н. Громов, ор. сit., p. 57; В.Г. БрюсовА, София Премудрость Божия..., p. 91; А. DечNекА, op. cit., p. 35; P. Hunt, Confronting the End..., p. 287; A. Tradigo, op. cit., p. 45.

${ }^{69}$ J. MeyendorfF, L'iconographie..., p. 274; Т.А. СидоровА, op. cit., p. 213, 220; В.Г. БрюсовА, Толкование.., p. 300; К.С. FецмY, ор. cit., p. 58; М.Н. Громов, op. cit., p. 57; Е.Б. ГромовА, op. cit., p. 13, 20; A. Deyneka, op. cit., p. 35; В. Пуцко, op. cit.; A. Tradigo, op. cit., p. 45.

${ }^{70} \mathrm{~J}$. Meyendorf, L'iconographie..., p. 274; Т.А. СидоровА, op. cit., p. 213, 220; В.Г. Брюсова, Толкование..., p. 300; Г.М. Прохоров, ор. cit., p. 13; К.С. FеLмY, op. cit., p. 58; Е.Б. ГромовА, op. cit., p. 13, 20; В.Г. БрюсовА, София Премудрость Божия..., p. 92, 97; Р. Hunт, Confronting the End..., p. 287; A. Tradigo, op. cit., p. 45.

${ }^{71}$ J. Meyendorff, L’iconographie..., p. 276; Т.А. СидоровА, op. cit., p. 214; К.С. Felmy, op. cit., p. 53; Л.М. ЕвсеЕвА, Пир Премудрости..., р. 196; В.Г. БрюСовА, Собия Премудрость Божия..., р. 92, 183; P. Hunt, Confronting the End..., p. 284. 
This gives the impression that it is an element which was ineptly combined with the image of a temple, probably added by a later author ${ }^{72}$. It is worth noting that although the conciliar scenes were shown fairly conventionally (each of the meetings of the clergy is chaired by the emperor sitting in the center of the congregation), the $16^{\text {th }}$ century artist included a few historical details. For example, in the depiction of the council in Chalcedon (451), which was held in the St. Euphemia Church there is a figure of a saint resting on her tomb; in the scene of the council in Nicaea of 787 the figures of two rulers: Empress Irene and her son Constantine $\mathrm{VI}$ can be seen ${ }^{73}$. In the uppermost part of the depiction there are seven angelic figures, included in medallions. Each of them holds a scroll with a different quotation from the Old Testament Book of Wisdom (Wis 2, 24; 1, 5; 2, 23; 1, 12; 1, 13; 2, 1) ${ }^{74}$. These figures probably represent the gifts of the Holy Spirit or the churches of the Apocalypse of John ${ }^{75}$.

Summing up, the icon is the most complete representation of the motif of Sophia's banquet. It contains many direct references to the text of the Book of Proverbs and to Christian symbolism (the sacrament of the Eucharist, the dogma of the incarnation of Christ). A novelty is, however, an attempt to extend the interpretational context of the artefact with a historical thread, represented by a fairly realistic depiction of seven ecumenical councils ${ }^{76}$.

At this point it is worth noting that the work may have served as a model for later artists. To this day, three $16^{\text {th }}$ century icons, carved in wood, have been preserved, which contain representations of Sophia's banquet, and show significant compositional and stylistic similarity to the above painting. Perhaps the oldest of them is a small icon, originally held in the collection of A.S. Uvarov, and currently in the collections of the State Historical Museum in Moscow (ГИМ, № ОК $9153)^{77}$. There is still a lack of unanimity as to the dating of the object. In the literature there is information that it was created at the end of the $15^{\text {th }}$ century ${ }^{78}$,

\footnotetext{
${ }_{72}^{72}$ М.Н. Громов, op. cit., p. 57; Р. Нunт, Confronting the End..., p. 281, 284, 290; В. Пуцко, op. cit.

${ }^{73}$ Т.А. Сидорова, ор. cit., p. 214; К.С. Fецму, ор. cit., p. 54; Л.М. ЕвСеЕвА, Пир Премудрости..., p. 196; A. Deyneka, op. cit., p. 35; A. Tradigo, op. cit., p. 45.

${ }^{74}$ Т.А. СидоровА, ор. cit., p. 214; К.С. FеLмy, op. cit., p. 53-54; Л.М. ЕвсеЕвА, Пир Премудрости..., p. 196; М.Н. Громов, op. cit., p. 57; В. Пуцко, op. cit.

75 Л.М. ЕвсеЕвА, Пир Премудрости..., p. 196; М.Н. ГрОмов, op. cit., p. 57; Е.Б. ГромовА, op. cit., p. 13; В.Г. Брюсова, София Премудрость Божия..., p. 97, 183; A. Tradigo, op. cit., p. 45.

${ }^{76}$ P. Hunt, Confronting the End..., p. 287.

77 А. Уваров, Резная икона "Премудрость созда себе дом", принадлежавшая пинскому князю Феодору Ивановичу Ярославичу, 1499-1522, Москва 1867, p. 8; Т.А. СидоровА, ор. cit., p. 212, pl. 3; И.И. ПЛЕшАновА, Два резных образка в собрании Русского Музея, Пку 1979/1980, р. 209, 210, 216-217; Г.М. Прохоров, ор. cit., p. 9; К.С. FецмY, op. cit., p. 53, 60; Е.Б. ГромовА, op. cit., p. 20; В.Г. БрюСОВА, Собия Премудрость Божия..., р. 117; В. ПуцКО, ор. cit.; С. ЗОЛОТАРЕВ, ор. cit., p. 303. ${ }^{78}$ А. УваРОВ, op. cit., p. 8; В. ПУцКО, op. cit.
} 
at the turn of the century ${ }^{79}$ or even in the first half of the $16^{\text {th }}$ century $y^{80}$. It has been suggested the icon was made in Novgorod ${ }^{81}$.

There is no doubt that the iconographic scheme in the icon clearly refers to the previous representations of the scene from Prov 9, 1-6, known to us from Russia. The personification of Divine Wisdom is placed on the left side of the depiction. Her figure inscribed in a circle is characterized by unprecedented delicacy. Sophia sits on the throne, supporting her feet on the footrest. She is enshrouded with ancient Greek robes, whose windswept ends seem to fall freely behind the back of the figure. The head of Lady Wisdom is revealed and adorned with a rhombus glory. In her right hand Sophia holds a sceptre and in her left most probably an Eucharistic chalice ${ }^{82}$. Right next to the figure of Divine Wisdom there is a table with two items, which would give rise to associations with the sacrament of the Eucharist: a cup of wine and a loaf of bread. Around them the servants of Sophia are bustling about: three of them are killing animals, one is pouring wine into cups and five of them are giving full cups to people ${ }^{83}$.

In the upper left corner, the house of Wisdom is represented by a three-aisled basilica, decorated with a portico supported by seven columns. There are also a few figures which had already appeared in the same context on the icon at the Tretyakov Gallery and described previously. On the right side there is an image of the Virgin sitting on a throne with the Child on her knees. It is surrounded by a circular nimbus. Just above the figure of the Virgin there are seven medallions with the busts of angels. Next to the facade of the house of Wisdom there are also two male figures holding scrolls in their hands. They may be interpreted as King Solomon and Cosmas of Maiuma ${ }^{84}$. Unfortunately, it is impossible to read the inscriptions now, due to a bad condition of the object.

The representation of the scene of Sophia's banquet on two other icons carved in wood should be regarded as a faithful representation of the same scheme that shaped the depiction on the icon from the collection of Uvarov. The examination of both will, therefore, be limited to the identification of the elements differentiating the three artefacts.

The perfectly preserved representation of Sophia, holding a feast in the house built by herself, can be found on a miniature relief icon, which now belongs to

\footnotetext{
79 Т.А. СидоровА, op. cit., pl. 3; Г.М. Прохоров, op. cit., p. 9; К.С. Felmy, op. cit., p. 60-61; Л.М. ЕвСеЕвА, Пир Премудрости..., р. 196; Е.Б. ГромовА, ор. cit., р. 20.

${ }^{80}$ И.И. ПЛЕШАНОВА, op. cit., p. 215.

81 Л.М. ЕвСеЕвА, Пир Премудрости..., р. 196.

${ }^{82}$ K.C. Felmy, op. cit., p. 60-61; В.Г. БрюсовА, София Премудрость Божия..., p. 117; В. Пуцко, op. cit.

${ }^{83}$ A. УВАРОВ, op. cit., p. 9; K.C. Felmy, op. cit., p. 61.

${ }^{84}$ А. УвАРОв, ор. cit., p. 8-9; К.С. FеLмY, op. cit., p. 60-61; Л.М. ЕвСеЕвА, Пир Премудрости..., p. 196; В.Г. БрюсовА, София Премудрость Божия..., p. 117.
} 
the collection of the State Russian Museum in St. Petersburg (ГРМ, № ДРД-47) ${ }^{85}$. It was made - according to the inscription on the reverse - by a priest named Ananias and then offered by Fyodor Ivanovič Yaroslavovič to Fyodor Ivanovič

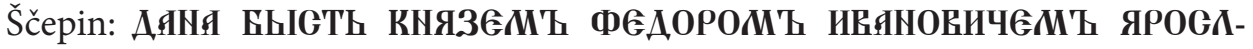
ВИЧЯ ФЕДОРОУ ИВЯНОВИЧОУ ЏЕПИНОУ РОБИКТ ПОП' ЯНЯНИЯ ${ }^{86}$. The first of the above-mentioned figures can be identified as the Duke of Pinsk Fyodor (died 1525) ${ }^{87}$. On this basis it should be assumed that the artefact was created in the Grand Duchy of Lithuania. Moreover, a paleographic analysis of the quote of Prov 9, 1-2 on the icon suggests that it was taken from the so-called Bible by Francis Skoryna - an old print issued early in 1517. The date of creation of the icon should therefore be limited to between 1517 and $1525^{88}$.

The personification of Divine Wisdom is represented in almost the same way as on the icon coming from the collection of A.S. Uvarov. Sophia sits on the throne, supporting her feet on the footrest. She is covered with a chiton and himation on her shoulder. Her head is uncovered and surrounded by a standard circular nimbus. In her left hand she holds a scroll and stretches out her right hand as a gesture of blessing. Interestingly, the gender of Sophia cannot be clearly defined. The figure is massive and the hair is short. Perhaps the intention of the author was to represent not a female personification of Divine Wisdom, but Christ Emmanuel. This can be proven by the inscription located next to the figure: HG XG. The figure of Sophia is surrounded by a circular nimbus with an inscription in the rim: 3IKAf GВОЯ ЖРТВИ ЧЕРПЯЕШЯ ЧШИ ВИНО (Prov 9, 2) ) $^{89}$

The scene of Sophia's banquet is presented in a fairly conventional way. Next to the figure of Sophia there is an empty table around which servants are bustling about: two of them kill animals, one pours wine, and others are giving filled cups to people gathered around them. Above this there is the façade of the house of Wisdom. King Solomon leans out from the balcony, holding a scroll with the text of Prov 9, 1: ПРМАРОGТЬ G03АЯ GOEG ХРМЬ И УТВРАИ ОТАП САМЬ. On the right side there is an image of the Mother of God with Child surrounded by a glory with a fragment of the Anaphora of St. John Chrysostom depicted in its rim:

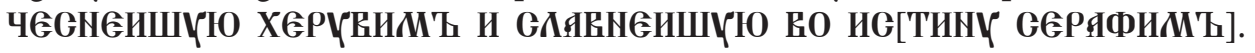

\footnotetext{
${ }^{85}$ Т.А. СидоровА, op. cit., p. 212; И.И. ПлЕшАНОвА, op. cit., p. 210-211, 216; Г.М. Прохоров, op. cit., p. 12; К.С. FеLмy, op. cit., p. 60, 62; Л.М. ЕвсеЕвА, Пир Премудрости..., p. 196; Е.Б. ГромовА, op. cit., p. 20; В.Г. Брюсова, София Премудрость Божия..., p. 115; В. ПуцКо, ор. cit.; С. ЗоЛотАРев, op. cit., p. 304.

${ }^{86}$ И.И. ПЛЕШАНОвА, ор. cit., p. 214; В.Г. БрЮСовА, Собия Премудрость Божия..., p. 115-116.

${ }^{87}$ А. УвАРОв, ор. cit., p. 4; Т.А. СИДОРОвА, ор. cit., p. 212; И.И. ПлЕШАНОвА, ор. cit., p. 209, 214; К.С. FецмY, ор. cit., p. 60-62; В.Г. БрюсовА, София Премудрость Божия..., p. 116; В. Пуцко, op. cit.; С. ЗОЛОТАРЕВ, op. cit., p. 304.

${ }^{88}$ В. ПуцКО, op. cit.

${ }^{89}$ И.И. ПлЕШАНовА, ор. cit., p. 211; К.С. Felmy, op. cit., p. 61; В.Г. БрюсовА, София Премудрость Божия..., p. 115; В. Пуцко, ор. сit.
} 
Below, there is a figure of Cosmas of Maiuma holding a scroll with a quote from the first stanza of the canon of the Matins of Holy Thursday: вGGRинНЯ ПОдЯTENHI МYАР[ОGТЬ]. In the upper part there are seven medallions with busts of angels. Above there is the following inscription: G0ФGH [ПРGМY]АРGTh БЖИЯ АЯНЯ БНІТЬ КНЗМЬ ФGАОРОМЪ ИВ ${ }^{90}$.

It should be added that one more icon carved in wood has survived to this day, which - thanks to the inscription in the upper part - can be considered an object prepared at the request of the Duke of Pinsk Fyodor Ivanovič Yaroslavovič. Interestingly enough, for a long time it was known solely thanks to a drawing from mid- $19^{\text {th }}$ century attached to an article devoted to Russian art in the museum collections of Paris ${ }^{91}$. The layout of the icon is almost identical to the abovediscussed depiction of the scene of Sophia's banquet. The differences are limited only to minor details, such as distribution of dishes on the table, lack of mandorla surrounding the angelic figures and minimal discrepancies in the method of staging the figures. The only element that makes it possible to give a clear (negative) answer to the question whether the icon from the Paris collection and that from the State Russian Museum, is the same one is the accompanying inscription. It can be read

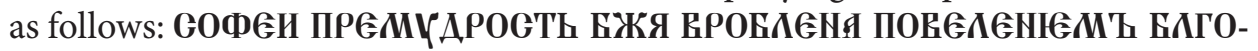
ВЕРНЯ КНЗЯ ФGДОРЯ ИВЯНОВІЧЯ ЯРОGАЯВЧЯ ${ }^{92}$.

An interesting representation of Sophia's banquet can be found in a part of a foldable icon, made in the $16^{\text {th }}$ century for the Ipatiev Monastery in Kostroma ${ }^{93}$. In this small artwork, carved in bone, there is Sophia sitting next to a richly laden table. Her figure was stylized to look similar to ancient images of muses: personified Wisdom is wearing a chiton and himation. Her head is uncovered and surrounded by a circular nimbus. Right next to Sophia's face there is an inscription: HG XG. Wisdom is accompanied by three servants: one of them in the foreground kills a calf, and two other give cups of wine to people gathered on the right side of the iconographic scheme. Above is the image of Mother of God, in a circular mandorla. In the upper left corner there is a representation of the house of Sophia,

\footnotetext{
${ }^{90}$ И.И. ПлЕШАНОВА, ор. cit., p. 211; К.С. FеLмч, op. cit., p. 61; В.Г. БРЮСовА, София Премудрость Божия..., p. 115; В. Пуцко, ор. сit.

${ }^{91}$ А. Уваров, ор. cit., p. 1; П. ЛЕБЕДИНЦЕв, София Премудрость Божия в иконографии Севера и Юга России, Киевская Старина 10, 1884, p. 565; Т.А. СидоровА, ор. cit., p. 212, pl. 4; И.И. ПлешАновА, op. cit., p. 209, 210; Г.М. Прохоров, оp. cit., p. 11; Е.Б. ГромовА, op. cit., p. 20; В.Г. БрюсовА, София Премудрость Божия..., р. 116; В. Пуцко, ор. сit.

92 А. Уваров, оp. cit., p. 1; П. ЛЕБЕДИНЦЕВ, op. cit., p. 565; К.С. FеLMY, op. cit., p. 61; В.Г. БРЮСОВА, Собия Премудрость Божия..., р. 116.

${ }^{93}$ Н.В. ПокРОвскиЙ, Древности Костромского Ипатьевского монастыря, ВАИ 4, 1885, р. 21; Т.А. Сидорова, ор. cit., p. 212, pl. 7; И.И. ПлЕшАновА, ор. cit., p. 211; К.С. FеLмҮ, op. cit., p. 53, 63; M.Н. Громов, op. cit., p. 57.
} 
next to which there are two male figures who look at Mary. Most probably they are King Solomon and Cosmas of Maiuma ${ }^{94}$.

The overview of Eastern Slavic art depicting the scene of Sophia's banquet, with reference to the compositional scheme worked out in Russia in the $14^{\text {th }}$ and $15^{\text {th }}$ centuries, should be concluded with a discussion of a $17^{\text {th }}$-century icon made for the Shelter of the Mother of God church, in the Rogozhskoe Cemetery of the Old Believers in $\mathrm{Moscow}^{95}$. At first glance, this painting seems to be a true copy of the above-described depictions. The figure of Divine Wisdom in a mandorla consisting of several concentric circles is located at the left side of the picture. In the foreground there is a table, around which servants are bustling about, two of them killing an animal, one pouring wine into cups which are then distributed to the assembled people. Just above this there are the figures of Solomon and Cosmas of Maiuma, holding scrolls in their hands. A huge building, the house of Wisdom is right behind the king. Over the head of the hymnographer there are eight medallions. The largest of them holds an image of the Virgin with Child, whereas the other contain busts of angels. The picture

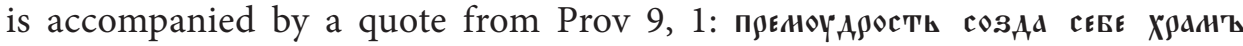

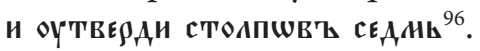

Where is the novelty then? At first, it should be emphasized that on the left side of the picture, i.e. in the place where one would expect to find a female personification of the Divine Wisdom, there is a figure of a long-bearded old man sitting on a throne, surrounded by angelic figures. He is enshrouded in a white robe and his head is surrounded by a nimbus of two rhombuses: red and brown. It should be assumed that this is a non-canonical depiction of God the Father like in the so-called Ancient of Days (in reference to the vision of the prophet Daniel ${ }^{97}$. The picture would be therefore one of the earliest pieces of evidence of the identification of Sophia with the First Hypostasis in Russian spirituality.

In the $17^{\text {th }}$ century, a separate depiction of Sophia's banquet, modeled upon Western European patterns, began to form among Eastern Slavs. It will not be discussed at this time, since it falls outside the chronological limits of this article ${ }^{98}$. Finally, it is worth noting that the considered motif appears in the post-Byzantine

\footnotetext{
${ }^{94}$ Н.В. ПокРовский, ор. cit., p. 22; Т.А. СидоровА, op. cit., p. 218; К.С. Felmy, op. cit., p. 63.

${ }^{95}$ Н.П. Кондаков, Лицевой иконописный подлинник, vol. I, Иконография Господа Бога и Спаса намего Iисуса Христа, Санкт-Петербург 1905, p. 88, pl. 34; Т.А. СидоровА, ор. cit., p. 212; В.Г. БрюсовА, Толкование..., p. 298; И.И. ПлешАновА, ор. cit., p. 210; К.С. FеLмч, op. cit., p. 53, 63. ${ }^{96}$ В.Г. БрюсовА, Толкование..., р. 298; К.С. FеLму, ор. сit., р. 63.

${ }^{97}$ K.C. Felmy, op. cit., p. 63.

${ }^{98}$ Discussion on the representations of the scene of Sophia's banquet from the $17^{\text {th }}$ and $18^{\text {th }}$ centuries can be found in the article: K.C. FeLmy, op. cit., p. 46-53.
} 
period paintings that decorate the monasteries in the area of Bukovina, including the Sucevița monastery $\left(16^{\text {th }} \text { century }\right)^{99}$.

In conclusion, the motif described in this article enjoyed great popularity in the art of Slavia Orthodoxa. At the turn of the $14^{\text {th }}$ century iconographic depictions, referring to Prov 9, 1-6, began to appear. Initially the scene of Sophia's banquet became common in South Slavic painting to arrive in Russia in the middle of the $14^{\text {th }}$ century. On the artefacts that illustrate the story of the ninth chapter of the Book of Proverbs, Sophia is usually represented as a young woman in ancient Greek robes (chiton and himation). Her head is surrounded by a distinctive nimbus, of two figures: a circle and a rhombus (in the Balkans) or two intersecting rhombuses (Russia). In the images of this type it is possible sometimes to see an attempt to identify Sophia with Christ.

\section{Bibliography}

\section{Secondary Literature}

Ammann A.M., Darstellung und Deutung der Sophia im vorpetrinischen Russland, OCP 4, 1938, p. $120-156$.

Balcarek P., The Image of Sophia in Medieval Russian Iconography and its Sources, Bsl 60, 1999, p. 593-610.

Brzozowska Z., The Church of Divine Wisdom or of Christ - the Incarnate Logos? Dedication of Hagia Sophia in Constantinople in the Light of Byzantine Sources from $5^{\text {th }}$ to $14^{\text {th }}$ century, SCer 2, 2012, p. 85-96;

Brzozowska Z., Sofia - Mądrość Boża. Przymiot, energia czy odrębna osoba Boska w teologii Kościoła wschodniego (do XVw.), Hy 20, 2013, p. 1-21

Brzozowska Z., Sofia - upersonifikowana Mądrość Boża. Dzieje wyobrażeń w kręgu kultury bizantyńsko-słowiańskiej, Łódź 2015.

Cvetrović B., Some Hierotopical Aspects of the New Jerusalem Programmes in the Fifteenth-century Serbia, [in:] Новые Иерусалимы. Иеротопия и иконография сакральных пространств, еd. А.М. Лидов, Москва 2009, p. 197-215.

Deyneka A., The Ackland Sophia: Contextualizing, Interpreting, and “Containing” Wisdom, Chapel Hill 2007.

Felmy K.C., "Die unendliche Weisheit, des Lebens Allgrund und Erschafferin". Die Ikonen der Weisheit und die Göttliche Liturgie, [in:] "Die Weisheit baute ihr Haus". Untersuchungen zu Hymnischen und Didaktischen Ikonen, ed. K.C. Felmy, E. Haustein-Bartsch, München 1999, p. 43-68.

FIEnE D.F., What is the Appearance of Divine Sophia?, SRev 48, 1989, p. 449-476.

Gligorijević-Maksimović M., Classical Elements in the Serbian Painting of the Fourteenth Century, ЗРВИ 44, 2007, p. 363-371.

${ }^{99}$ I.D. ŞTEFĂNESCU, op. cit., p. 140, 141-142, 164; A.M. AMMANN, op. cit., p. 145; N. IsAR, L'espace iconique - inscription et transfiguration. La rhétorique paradoxale de l'image sacrée à l'age post-byzantin, SeS 3/4, 2005/2006, p. 203, 204, 207, pl. 2. 
Grabar A., Sur les sources des peintres byzantins des XIII' et XIV siècles, CAr 12, 1962, p. 351-380.

Hunt P., Confronting the End. The Interpretation of the Last Judgment in a Novgorod Wisdom Icon, Bsl 65, 2007, p. 275-325.

Hunt P., The Wisdom Iconography of Light. The Genesis, Meaning and Iconographic Realization of a Symbol, Bsl 67, 2009, p. 55-118.

IsAR N., L'espace iconique - inscription et transfiguration. La rhétorique paradoxale de l'image sacrée à l'age post-byzantin, SeS 3/4, 2005/2006, p. 199-224.

Lifšic L., Die Ikone "Sophia - Weisheit Gottes” aus der Sammlung der Museen des Moskauer Kreml'. Zur Frage nach der Herkunft und der Zeit des ersten Auftauchens des sogenannten "Novgoroder" ikonographischen Typs, [in:] "Die Weisheit baute ihr Haus". Untersuchungen zu Hymnischen und Didaktischen Ikonen, ed. K.C. Felmy, E. Haustein-Bartsch, München 1999, p. 29-41.

Lifšic L., La Sapienza nell'iconografia russa, [in:] Sophia. La Sapienza di Dio, ed. G.C. Azzaro, P. Azzaro, Milano 1999, p. 57-65.

LikhaChov D., Novgorod. Art Treasures and Architectural Monuments $11^{\text {th }}-18^{\text {th }}$ centuries. Architecture. Frescoes. Archeological Artefacts. Minor Arts. Icons. Illuminated MSS, Leningrad 1984.

Likhachov D., Laurina V., PushKariov V., Novgorod Icons $12^{\text {th }}-17^{\text {th }}$ century, Leningrad 1980.

Lilienfeld F.v., "Frau Weisheit" - in Byzantinischen und Karolingischen Quellen des 9. Jahrhunderts - allegorische Personifikation, Hypostase oder Typos?, [in:] EADEM, Sophia - die Weisheit Gottes. Gesammelte Aufsätze 1983-1995, Erlangen 1997, p. 111-150.

Marini Clarelli M.V., Personificazioni, metafore e alegorie nell'arte paleologa, [in:] L'arte di Bisanzio e l'Italia al tempo del Paleologi 1261-1453, ed. A. IACobini, M. Della Valle, Roma 1999, p. 55-67.

Martens-Czarnecka M., The Wall Paintings from the Monastery on Kom H in Dongola, Warszawa 2011.

Meyendorff J., L'iconographie de la Sagesse Divine dans la tradition byzantine, CAr 10, 1959, p. 259-277.

Meyendorff J., Wisdom-Sophia: Contrasting Approaches to a Complex Theme, DOP 41, 1987, p. 391-401.

Nersessian S. DER, Note sur quelques image se rattachant au thème du Christ-Ange, CAr 13, 1962, p. 209-216.

Nersessian S. DER, Program and Iconography of the Frescoes of the Parecclesion, [in:] The Kariye Djami, vol. IV, Studies in the Art of the Kariye Djami and Its Intellectual Background, ed. P.A. Underwood, London 1975, p. 303-349.

Osterrieder M., Das Land der Heiligen Sophia: das Auftauchen des Sophia-motivs in der Kultur der Ostslaven, WSA 50, 2002, p. 5-62.

Petrović V.R., La peinture Serbe du Moyen Âge, vol. I, Belgrad 1930.

RAdojčić S., La table de la Sagesse dans la literature et l'art serbes, ЗРВИ 16, 1975, p. 215-224.

Sophia. La Sapienza di Dio, ed. G.C. Azzaro, P. Azzaro, Milano 1999.

ŞTEFĂNESCU I.D., L'illustration des liturgies dans l'art de Byzance et de l'Orient, Bruxelles 1936.

Sulikowska-Gąska A., Spory o ikony na Rusi w XV i XVI w., Warszawa 2007.

Tenace M., Le sens des représentations de la Sophia comme ange dans la tradition orthodoxe russe.

Un pont entre teologie, philosophie et art, JEaCS 59, 2007, p. 261-280.

Todić B., Serbian Medieval Painting. The Age of King Milutin, Belgrade 1999. 
Todić B., Tradition et innovations dans le programme et l'iconographie des fresques de Dečani, [in:] Dečani et l'art Byzantin au milieu du XIV siecle. A l'occasion de la celebration de 650 ans du monastere de Dečani. Septembre 1985, ed. V.J. DJuRIć, Beograd 1989, p. 251-271.

Tradigo A., Ikony i święci prawosławni, trans. E. Maciszewska, Warszawa 2011.

Tsamakda V., Darstellungen der Hagia Sophia bzw. der Weisheit Gottes in der kretischen Wandmalerei, BZ 101, 2008, p. 209-230.

Uspienski L., Teologia ikony, trans. B. DĄB-Kalinowska, Poznań 1993.

Алпатов М.В., Фрески иеркви Успения на Волотовом Поле, Москва 1977.

Бојовит Д., Трпеза Премудрости, Београд-Ниш 2009.

Брюсова В.Г., София Премудрость Божия в древнерусской литературе и искусстве, Москва 2006.

Брюсова В.Г., Толкование на IX Притчу Соломона в Изборнике 1073 г., [in:] Изборник Святослава 1073 г. Сборник статей, еd. Б.А. РыБАков, Москва 1977, р. 292-306.

Вздорнов Г.И., Волотово. Фрески иеркви Успения на Волотовом поле близ Новгорода, Москва 1989.

Вздорнов Г.И., Искусство книги в Древней Руси. Рукописная книга Северо-Восточной Руси ХІІ - начала XV вв., Москва 1980.

Вздорнов Г.И., Исследование о Киевской Псалтири, Москва 1978.

Володина Т.В., Культура региона: художественная культура Великого Новгорода. Избранные страниць, Великий Новгород 2002.

Глигоријевић-МАксимовић М., Иконографија Богородичиних праобраза у српском сликарству од средине XIV до средине XV века, ЗРВИ 43, 2006, p. 281-317.

Громов М.Н., Образ сакральной Премудрости, [in:] М.Н. Громов, В.В. Мильков, Идейные течения древнерусской мыссли, Санкт-Петербург 2001, p. 44-59.

Громова Е.Б., "Премудрость созда себе дом" в богословской и изобразительной традиции ХIV в., [in:] Сербско-русские литературные и культурные связи XIV-XX вв., еd. Л.К. ГАврюшинА, Санкт-Петербург 2009, р. 6-23.

Ђортевит И.М., Дарови Светог Духа у проскомидији Богородичине иркве у Морачи, [in:] The Monastery of Morača, ed. B. Todić, D. Popović, Belgrade 2006, p. 195-211.

Евсеева Л.М., Две символические композиции в росписи ХIV в. Монастыря Зарзма, ВВ 43, 1982, p. 134-146.

Евсеева Л.М., Пир Премудрости, [in:] София Премудрость Божия. Выставка русской иконописи XIII-XIX вв. из собраний музеев России, Москва 2000, р. 194-197.

Живковит Б., Грачанииа. Цртежи фресака, Београд 1989.

ЗолотАРев С., София Премудрость Божия. Проблемы и перспективы религиозно-философского и искусствоведческого осмысления, ГРЦР 44/45, 2008, р. 228-330.

Киевская Псалтирь 1397 года из Государственной Публичной Библиотеки имени М.Е. Салтькова-Щедрина в Ленинграде [ОЛДП F 6], еd. Т.В. ЮровА, Москва 1978.

КолПакова Г.С., Искусство Византии. Поздний период, Санкт-Петербург 2010.

Кондаков Н.П., Лицевой иконописный подлинник, vol. I, Иконография Господа Бога и Спаса нашего Іисуса Христа, Санкт-Петербург 1905. 
ЛАзарев В.Н., Мозаики Собии Киевской, Москва 1960.

ЛЕьединцев П., София Премудрость Божия в иконографии Севера и Юга России, КСта 10, 1884, p. 555-567.

Лифшиц Л., Премудрость в русской иконописи, ВВ 61, 2002, p. 138-150.

Лифшиц Л., София Премудрость Божия в русской иконописи, [in:] София Премудрость Божия. Выставка русской иконописи XIII-XIX вв. из собраний музеев России, Москва 2000, p. 9-17.

ЛИХАчев Д.С., ВАГНЕР Г.К., ВЗДОРНОВ Г.И., СКРЫнНИКОв Р.Г., Великая Русь. История и художественная культура X-XVII в., Москва 1994.

Мейендорф И.Ф., Тема Премудрости в восточноевропейской средневековой культуре и ее наследие, [in:] Литература и искусство в системе культуры, еd. Б.Б. Пиотровский, Москва 1988, р. 244-252.

Пивоварова Н., Премудрость и Церковь, [in:] София Премудрость Божия. Выставка русской иконописи XIII-XIX вв. из собраний музеев России, Москва 2000, p. 324-325.

ПлешАнова И.И., Два резных образка в собрании Русского Музея, Пку 1979/1980, p. 209-217.

Покровский Н.В., Древности Костромского Ипатьевского монастыря, ВАИ 4, 1885, p. 1-34.

Покровский Н.В., Евангелие в памятниках иконографии преимущественно византийских и русских, Москва 2001.

Прашков Л., Хрелева башня Рильского монастыря и ее стенопись, [in:] Древнерусское искусство. Зарубежные связи, Москва 1975, р. 147-171.

Прохоров Г.М., Послание Титу-иерарху Дионисия Ареопагита в славянском переводе и иконограбия “Премудрость созда себе дом", ТОДЛ 38, 1985, p. 18-41.

Пуцко В., Резная деревянная икона пинского князя, ГБ 23, 2008.

РАдојчит С., О Трпези Премудрости у српској кюижевности и уметности од раног ХІІІ до раног XIX в., [in:] ІDEм, Одабрани чланци и студије 1933-1978, Београд-Нови Сад 1982, p. 223-229.

РАдојчит С., Старо српско сликарство, Београд 1966.

РАдојчИЋ С., Улога антике у старом српском сликарству, [in:] IDEм, Одабрани чланци и студије 1933-1978, Београд-Нови Сад 1982, р. 65-73.

РАдојчић С., Фреске Марковог Манастира и живот св. Василија Новог, ЗРВИ 4, 1956, p. 215-227.

САРаБьянов В.Д., СмИРнова Э.С., История древнерусской живописи, Москва 2007.

Сидорова Т.А., Волотовская фреска “Премудрость созда себе дом" и ее отночение к новгородской ереси стригольников в ХІV в., ТОДЛ 26, 1971, p. 212-231.

Смирнова Э.С., Миниатюры двух новгородских рукописей, [in:] Древнерусское искусство. Рукописная книга, Москва 1983, р. 180-203.

Тодић Б., Грачанища. Сликарство, Приштина 1999.

Уваров А., Резная икона “Премудрость созда себе дом", принадлежавшая пинскому князю Феодору Ивановичу Яроставичу, 1499-1522, Москва 1867.

Флоровский Г.В., О почитании Софии, Премудрости Божией, в Византии и на Руси, [in:] Догмат и история, Москва 1998, p. 394-414.

ЧХенкелИ М., Символическая связь Премудрости Божией и Евхаристии в сербском монументальном искусстве XIII-XIV в., CRe 4, 2010, p. 132-142.

Яковлева А.И., “Образ мира” в иконе “София Премудрость Божия”, [in:] Древнерусское искусство. Проблемы и атрибуции, еd. В.Н. ЛАЗАРев, О.И. ПодОБЕДОВА, Москва 1977, p. 388-404. 


\begin{abstract}
Sophia's banquet (Divine Wisdom's banquet) - this type of iconography is an illustration of a specific passage of the ninth chapter of the Old Testament Book of Proverbs: Wisdom hath built herself a house (Prov 9, 1-6). That text became widespread in Old Russian literature within liturgical books containing passages of the Old Testament. Also the comment of Anastasius Sinaites for Proverbs 9, 1-6 was translated into Old Church Slavonic. Iconographic images of the Wisdom's banquet scene should be considered as a phenomenon typical of South Slavic wall paintings from the period of fourteenth century. Later on, the discussed motif became popular in Old Russian art and began to appear on the East Slavic icons.
\end{abstract}

Keywords: Sophia, Divine Wisdom, Book of Proverbs, medieval Slavic art

Zofia Brzozowska

Katedra Filologii Słowiańskiej

Wydział Filologiczny

Uniwersytet Łódzki

ul. Pomorska 171/173

90-236 Łódź, Polska/Poland

caryca_zofia@wp.pl 


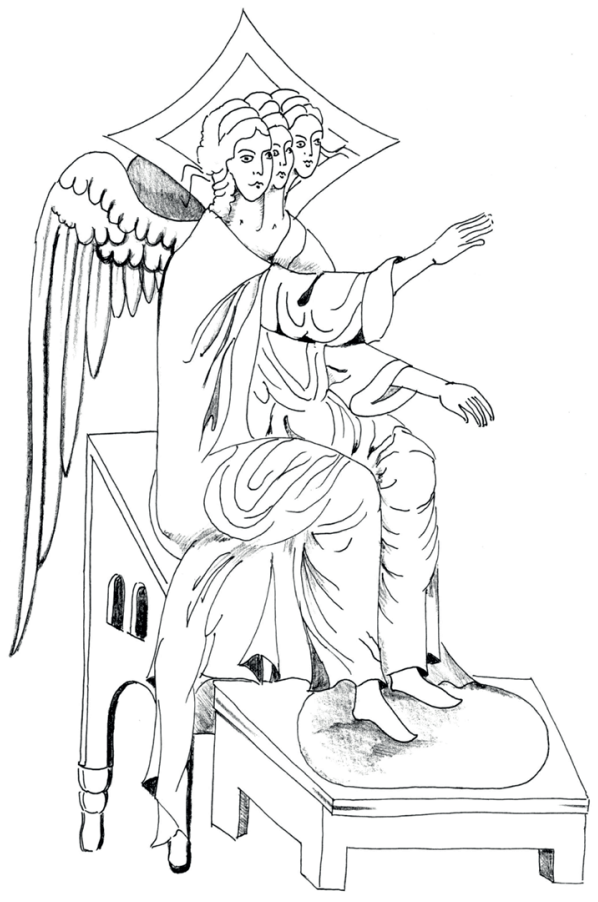

Ill. 1. Three-headed personification of Divine Wisdom from the scene of Sophia's banquet (Prov 9, 1-6). The eastern wall of the narthex of the Church of Entrance of the Holy Mother of God into the Temple (a part of the Hilandar Monastery on Mount Athos), 1320-1321. Drawing by E. Myślińska-Brzozowska.
Ill. 2. Sophia's banquet - a painting on the eastern wall of the altar in the Church of the Annunciation in the Serbian Gračanica Monastery, 1321. The Old Church Slavonic inscription in the upper register quotes Prov 9, 1. Drawing by E. Myślińska-Brzozowska. $\therefore$ MPSMPPOCTO CO $\overrightarrow{J^{A}}$ CEET XPAM16.

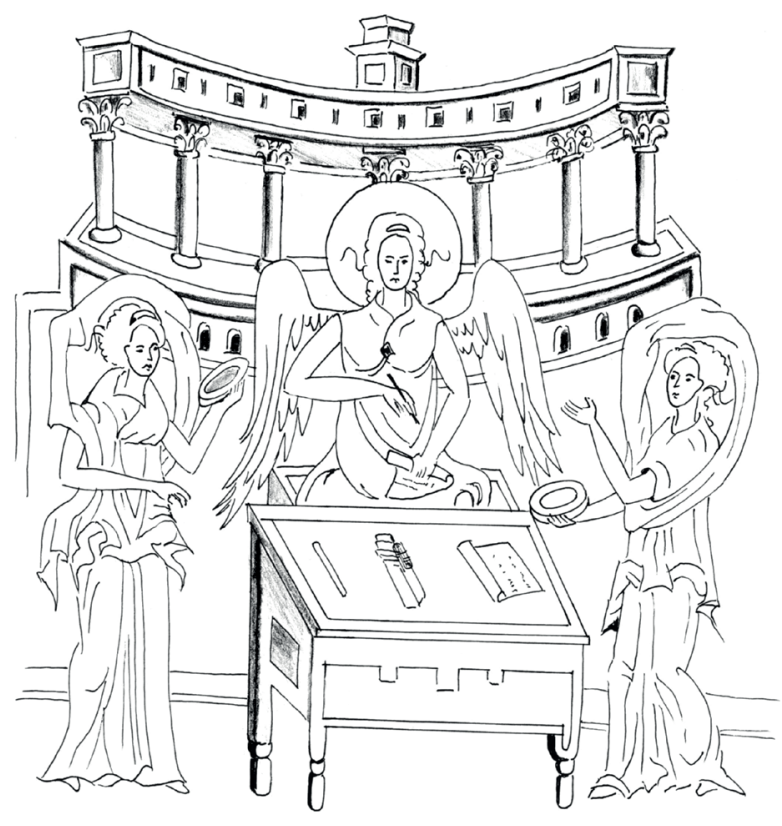

